Preprints of the

Max Planck Institute for

Research on Collective Goods

Bonn 2006/27

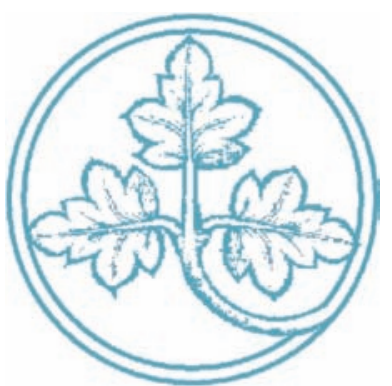

How Much Collusion?

A Meta-Analysis On

Oligopoly Experiments

Christoph Engel

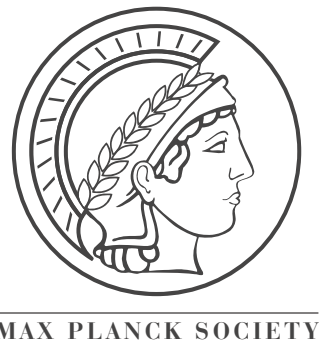




\section{How Much Collusion? A Meta-Analysis On Oligopoly Experiments}

Christoph Engel

December 2006 


\section{How Much Collusion? A Meta-Analysis On Oligopoly Experiments}

I. Research Question 2

II. Methodology 3

$\begin{array}{ll}\text { III. Dependence of Collusion on Product Characteristics } & 7\end{array}$

1. Homogeneity vs. Heterogeneity of Goods $\quad 7$

2. Effect of Introducing Fixed Costs 10

3. Effect of Constrained Capacity 10

4. Effect of Advance Production 12

5. Collusion when Process Innovation in Possible 13

IV. Dependence of Collusion on Market Characteristics 14

1. Effect of Market Size 14

2. Symmetry vs. Asymmetry of Sellers 17

3. Effect of Power Asymmetries among Sellers 19

V. Dependence of Collusion on Demand and Supply Characteristics 20

1. Effect of Demand Characteristics 20

2. Effect of Supply Characteristics 21

3. Dependence of Collusion on the Distribution of the Surplus 22

VI. Dependence of Collusion on Seller Characteristics 23

VII. Role of Seller Interaction in Explaining Collusion 24

1. Dependence on the Strategic Variable 24

2. Simultaneous vs. Sequential Interaction 26

3. Duration of the Interaction between Sellers 27

4. Partner vs. Stranger Design 29

5. Effect of Communication on Collusion 31

6. Option to Agree 33

VIII.Dependence of Collusion on the Information Environment 36

1. Role of Ex Ante Information 36

2. Role of Feedback 39

3. Neutral vs. Market Frame 42

IX. Sensitivity of Collusion to Buyer Activity 43

1. Computer vs. Human Buyers 43

2. Sensitivity of Collusion to the Trading Institution 43

3. Collusion under Conditions of Demand Inertia 45

X. Conclusion 46

* I Im grateful to Werner Güth, Reinhard Selten, Martin Hellwig, Martin Beckenkamp, Thomas Gaube and Frank Maier-Rigaud for their advice, and to Lena Heuner for her help in tracing old papers. 


\section{Research Question}

Richness can be embarrassing. Oligopoly has been among the first topics in experimental economics, starting as early as 1959 (Hoggatt 1959; Selten and Sauermann 1959). In the meantime, a total of 154 experimental papers has been published ${ }^{1}$. Many of them report on more than one experiment, so that there is data on much more than 500 different parameter constellations ${ }^{2}$. There is a number of survey articles (Friedman 1969; Plott 1982; Plott 1989; Davis and Holt 1993; Holt 1995; Lupi and Sbriglia 2003; Huck, Normann et al. 2004; Suetens 2004; Suetens and Potters 2005). But the latest comprehensive survey is a decade old. Moreover, it does not make the findings comparable across publications. This is undertaken in the present meta-study. It uses a simple question to turn the richness of the material into a boon: how much collusion have the respective experimenters found? More than one would normatively want? And more than game theory would expect?

Specifically, this study not only compares what experimenters have set out to test. In order to test subjects on their respective research question, they had to specify a whole array of other parameters, like product characteristics, market size, the shape of supply and demand, the strategic variable, the duration of the game, communication protocols, the information environment, and trading institutions. That way they have generated a rich body of data that has remained untapped thus far. This meta-study makes this data available.

This richness of the data has a third advantage. The sample is large enough to make many interaction effects significant. The most important ones are presented here.

Actually, these questions are not only helpful in generating order. They are also decisive for the main users of oligopoly experiments: the antitrust authorities. There are two main ways how these authorities may put experimental findings to productive use. Even in legal orders as dedicated to antitrust enforcement as the US, the European Community or Germany, administrative resources are limited. Knowing which factors facilitate collusion most helps these authorities detect instances of collusion.

Yet the relevance is not confined to administrative policy. Getting the expected degree of collusion right also matters in doctrinal terms. Both in the $\mathrm{US}^{3}$ and in Europe, ${ }^{4}$ merger control intervenes if the fact that a previously independent commercial entity disappears from the market makes "tacit collusion" substantially more likely. The behavioural evidence helps antitrust authorities in their ensuing predictive task. For them, understanding interaction effects is particu-

\footnotetext{
For references see the list at the end of this paper.

For the reasons laid out in section II, this study covers 510 independent observations.

Department of Justice, Federal Trade Commission, Antitrust Division, 1992 Horizontal Merger Guidelines of September 10, 1992, 57 FR 41552, Section 2.1.

4 Court of First Instance, 6 June 2002, Airtours plc v Commission of the European Communities, European Court Reports 2002 II 2585, at para. 60; Guidelines on the Assessment of Horizontal Mergers under the Council Regulation on the Control of Concentrations between Undertakings, OJ 2004 C 31/5, para. 22, 39,
} 41 
larly relevant. They have to find out whether the co-presence of two or more factors makes it more or less likely that collusion happens.

The remainder of this article is organised as follows. Section II specifies the methodology. Section III presents the evidence on product characteristics. Section IV addresses market structure, section V supply and demand, section VI seller characteristics, section VII seller interaction, section VIII the information environment, and section IX buyer activity. Section X concludes.

\section{Methodology}

Individual experimental papers often excel in sophistication. They for instance offer complex theoretical models for explaining the data. Recently, a wealth of learning theories has been used for the purpose (see in particular Sherman 1969; Shubik, Wolf et al. 1971; Cox and Walker 1998; Nagel and Vriend 1999b; Nagel and Vriend 1999a; Rassenti, Reynolds et al. 2000; Capra, Goeree et al. 2002; Offerman, Potters et al. 2002; Anderhub, Güth et al. 2003; Bosch-Domènech and Vriend 2003; Altavilla, Luini et al. 2005). Others present demanding statistical models (e.g. Daughety and Forsythe 1987; Benson and Faminow 1988; Davis, Reilly et al. 2003; Davis and Wilson 2005). Most papers give graphical information on time series. None of this works for a study that aims at being as encompassing as possible. The reason is simple. Many publications do not offer the data one would need for the purpose.

One information, however, is hardly ever missing: which has been the effect of the respective treatment on the strategic variable of the oligopolists (which is normally either price or quantity)? Specifically, in the large majority of papers, this information is given per instance of interaction. If the author has not done so anyhow, it is easy to calculate the mean for all rounds of interaction. Of course, duration matters. In a typical experiment, there is a pronounced change from the initial rounds over the middle of the game towards end effects (Selten and Stoecker 1986). If one adds many more rounds, the characteristic picture may reverse (Alger 1987). But duration varies so profoundly from experiment to experiment that only comparing aggregates is feasible. Since the number of rounds from which the mean is taken is always reported, one may control the result for total duration.

Absolute price or quantity is not meaningful across experiments. One needs a standardised benchmark. Actually, in oligopoly games there are three such benchmarks: the Walrasian and the collusive benchmarks always exist. In the standard Bertrand situation, the Walrasian and the Nash benchmark coincide (Bertrand 1883). But when marginal cost is not constant, or when firms compete in quantity, to name only the two most important reasons, the Nash equilibrium predicts a different outcome. Typically, it is between the Walrasian and the collusive expectations. This makes for the following picture. 


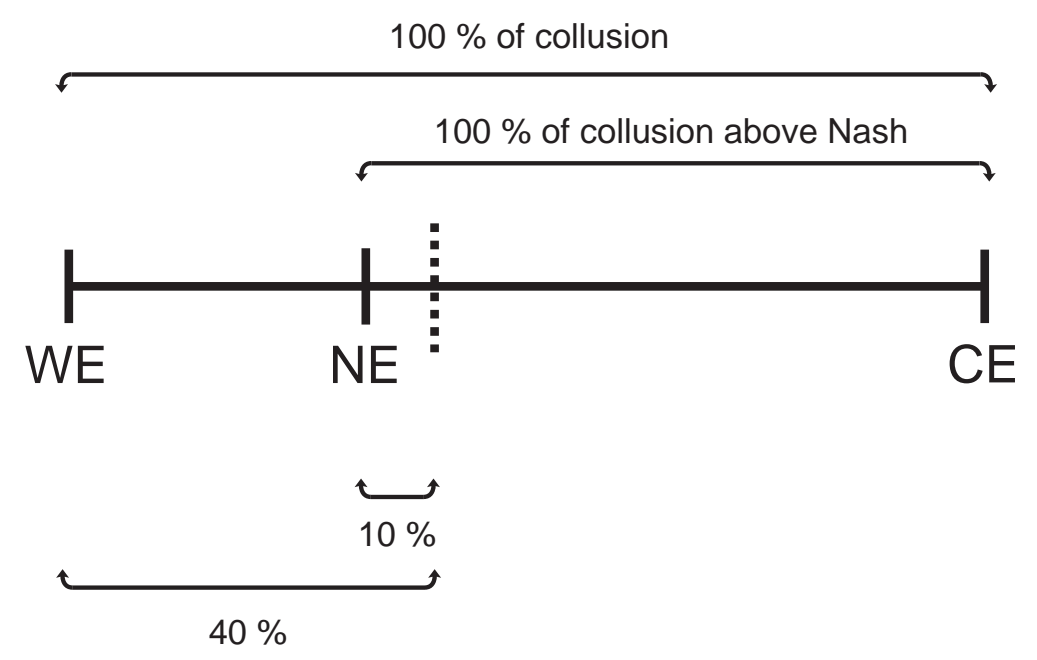

Figure 1

Normalized Benchmarks

The distance between the Walrasian equilibrium WE and the collusive equilibrium CE is defined as $100 \%$ of collusion. The dashed line is an example for the reported value of the strategic variable, say price. In the example, this value lies $40 \%$ above the Walrasian level. This index is reported as CW. However, compared to the Nash equilibrium, there is only $10 \%$ collusion. This is due to the fact that the span for calculating this index only covers the distance between the Nash equilibrium NE and the collusive equilibrium CE. It is reported as CN.

Of course, the reported value may be below the Nash equilibrium. In that case, the degree of collusion above Nash is indicated by a negative number. The distance to the left of the Nash equilibrium point is expressed as a fraction of the distance between NE and CE. Sometimes the reported value is even below WE. In that case, also the distance from WE to the left is expressed as a fraction of the distance between WE and CE, and it carries a negative sign. If the strategic variable is quantity, a small number means a high degree of collusion. To capture this, the reported quantity is normalised by how much it lies below, not above the Walrasian expectation.

There is one study in the literature following a similar approach. It compares experiments on Cournot games, and investigates how the number of sellers in the market matters (Huck, Normann et al. 2004). This study has introduced a different index. For all papers included in that meta-study, it calculates

$$
\frac{\bar{Q}}{Q_{N}}
$$

It thus expresses mean quantity from the experiment as a fraction of the respective Nash expectation. This is a less reliable measure. It is sensitive to arbitrary changes in the level of $Q_{N}$. This becomes patent in experiments that use an identical relative specification of demand and supply, but shift the level of the Walrasian equilibrium from experiment to experiment. Experimenters 
sometimes have done so in order to exclude parameter learning (for an example see Isaac, Ramey et al. 1984) $)^{5}$. Moreover, this index generates high values if $Q_{N}$ is very small, and low values if $Q_{N}$ is very high in absolute terms. And it cannot be calculated if an experimenter has normalised $Q_{N}=0$. For three reasons, this index is nonetheless calculated wherever possible. It is reported as NN. First it makes comparisons easier with the (small) set of papers in the literature that presents this index. Occasionally the $\mathrm{CN}$ index suffers from a mirror problem. If the Nash equilibrium is close to the collusive equilibrium, this index grows very large. In the experiments covered by this study, however, this is a rare event. Most importantly, however, there are several treatment variables where the $\mathrm{NN}$ index is significant, while the $\mathrm{CN}$ index is not.

60 of the 510 experiments covered in this study use a stranger design. In every round, subjects are rematched. Behaviourally speaking, this is not the same as one-shot interaction. From round 2 on, subjects come with the expectations built in previous rounds. But it at least is as good an approximation as is feasible with the experimental method. In the remaining 460 experiments, however, interaction is repeated. As is known from the folk theorem, this leads to multiple Nash equilibria if there is uncertainty about the end of the game (Aumann and Shapley 1994). Of course, the data on repetition effects is reported here. However, for calculating the Nash benchmark, repetition is ignored. The benchmark is always taken from the one-shot game.

The large majority of the experiments covered in this study use a computer to simulate the opposite market side. This computer is programmed as a non-strategic actor. It simply represents the demand curve. Equilibrium analysis becomes much more demanding if there are strategic actors on both sides of the market. In order to make the data comparable across treatments, this element of the situation is ignored when calculating the Nash equilibrium in the minority of experiments with human buyers. The benchmark is always exclusively taken from the interaction between sellers, i.e. assuming passive buyers.

The number of papers which themselves calculate one of the three indices is very small (see e.g. Cason and Davis 1995). But generating them is straightforward if the benchmarks and the means are reported. This, however, is often not the case. Whenever possible, these calculations have been done in preparation of this meta-study. Often this meant optimisation calculus. If the Walrasian benchmark was missing, often the industry demand and supply functions had to be constructed from firm functions, or directly from the cost functions. Occasionally, the reported values had to be weighted for calculating the means, for instance if discrete outcomes had different frequencies. The data bank behind this paper specifies which parameters could not be taken directly from the respective paper, and it explains which kind of judgement has been exercised in so doing, if necessary. It is publicly available.

Following the theory of induced valuation (Smith 1976), in the Seventies and Eighties, many experimenters have given their subjects step functions for supply and demand. Determining the

5 Take the following simple example: in the first experiment, $\mathrm{WE}=0, \mathrm{CE}=100, \mathrm{NE}=50$, experimental data 40. In this case, the index is $40 / 50=0,8$. Now shift the scale by 100 , leaving relative positions unaffected. Now $\mathrm{WE}=100, \mathrm{CE}=200, \mathrm{NE}=150$, experimental data 140 . Now the index is $140 / 150=0,9333$. 
Walrasian equilibrium is straightforward with step functions. It is the point where the two step functions cross. Calculating the collusive equilibrium requires trial and error, but is doable. However, since these functions are characterised by discontinuities, there is often no Nash equilibrium in pure strategies. Calculating the mixed equilibria is theoretically possible, but it is a formidable task (Holt and Solis-Soberon 1992). If the authors themselves have done so, and if they have come up with a single equilibrium, the expected value is taken as the Nash benchmark. But the effort for doing so for all the remaining papers with step functions would have been prohibitive. Instead, it is only checked whether there is a Nash equilibrium in pure strategies (at or directly above the Walrasian equilibrium). If this is not the case, the two indices relying on the Nash equilibrium are left blank. This is the main, but not the only reason why it has not been possible for all papers to calculate all three indices. The databank specifies which indices are missing, and for which reason. In the presentation of the results, for each index the composition of the sample is presented separately.

47 papers have a pertinent topic, but are not included in this meta-study. There are different reasons for excluding them. Most frequently, in the paper there are only graphs, but no exact numbers for calculating the means. In other cases, it is not possible to calculate the benchmarks, for instance because a step function is only presented graphically and measurement scales cannot be reconstructed from the graph. Sometimes, the research question is too far away, for instance if the experimenters have given their subjects so little information that it is meaningless to talk about collusion. Finally, some papers do not give summary statistics, but exclusively regressions, and the model is such that the data relevant for this comparative paper cannot be reconstructed. Also, experiments on spatial competition are excluded.

The data is presented the following way. The main effect of each treatment variable is calculated three times. The first calculation covers all experiments with the respective feature. It is called the gross data. Some papers do not report the standard variable. They for instance do not indicate industry profit, or the necessary elements for calculating it, when sellers are asymmetric. In such cases, the best available proxy is taken for calculating the indices. ${ }^{6}$ Other papers do not give data for all rounds of repetition, but only for some of them. Such somehow unusual data is excluded from the second calculation. It is called ordinary coverage. Finally, the effect is calculated a third time with data taken only from those experiments where this was a treatment variable. This is called the treatment data.

All effects are tested for significance by way of ANOVA. That way, interaction effects can be analysed as well. The samples are relatively large. However, variance might not always be homogeneous in subsamples. Moreover, the number of cases in each subsample is not always balanced. For both reasons, ANOVA results might not be fully reliable (see Hays 1994:10.20). Therefore, as a double-check, the main effects are also tested with a non parametric test. ${ }^{7}$ If the independent variable is dichotomous, a Mann Whitney U Test is used. If the independent vari-

6 The respective proxy is specified in the data bank.

$7 \quad$ Reinhard Selten had suggested to do so. 
able has more than two categories, a Kruskal Wallis test is applied (as suggested by Bortz 2005:287). In most cases, the p-values are similar. Not so rarely, the non parametric test even yields a smaller p-value than the ANOVA.

In order to save space, insignificant findings are not presented. Weakly significant findings $(p<0,1)$ are reported where the result seems sufficiently relevant. The treatment data, however, is always reported. This is justified since experimenters themselves had to check for significance. The results of the non parametric test are only presented if the ANOVA has yielded a significant result.

\section{Dependence of Collusion on Product Characteristics}

\section{Homogeneity vs. Heterogeneity of Goods}

If products are (imperfect) substitutes, producers each have their own niche. There is some competitive pressure, but competition is monopolistic (Chamberlin 1933). Consequently, sellers should do better if there is heterogeneity of products. This expectation is borne out if one compares experimental data to the Walrasian equilibrium. In such markets sellers typically charge different prices, and they sell different quantities. Therefore the strategic variable is not a good indicator of collusion. Wherever possible, it is replaced by industry profit. ${ }^{8}$

\begin{tabular}{|l|r|r|r|r|r|}
\hline gross & CW & CW (SD) & CW NOS & CW ANOVA & $\begin{array}{l}\text { CW Mann- } \\
\text { Whitney }\end{array}$ \\
\hline homogeneous & 30,0403023 & 40,1702612 & 419 & 0 & 0 \\
\hline heterogeneous & 67,4634146 & 26,0427925 & 91 & & \\
\hline $\begin{array}{l}\text { ordinary cov- } \\
\text { erage }\end{array}$ & OC CW & OC CW (SD) & OC CW NOS & OC CW ANO- & \\
\hline homogeneous & 18,4556962 & 30,8799469 & 237 & 0,001 & \\
\hline heterogeneous & 42,1052632 & 21,7967753 & 19 & & \\
\hline treatment & T CW & T CW (SD) & T CW NOS & T CW ANOVA & \\
\hline homogeneous & 42,8 & 38,317098 & 5 & 0,003 & 0,058 \\
\hline heterogeneous & 79,7647059 & 22,2779397 & 34 & & \\
\hline
\end{tabular}

Table 1

Homogeneity: Normalized Deviation from the Walrasian Equilibrium

(Legend: CW: Normalized Deviation from the Walrasian Equilibrium

SD: Standard Deviation

NOS: Number of Observations

ANOVA: Univariate Analysis of Variance

OC: sample reduced to experiments with Ordinary Coverage

$\mathrm{T}$ : sample reduced to experiments where homogeneity was a Treatment variable) 
Provided cost structures are similar, if products are heterogeneous, game theory expects an outcome above the competitive equilibrium for each of the products; there is much less competitive pressure after all. The empirical picture is not very clear. The only weakly significant result is on the NN index in the gross sample. There is collusion in both types of markets, but it is much stronger with homogeneous products. The treatment data from the $\mathrm{CN}$ index is insignificant, but points into the same direction. However, the treatment data on the NN index has the opposite result. This result too, however, is insignificant.

\begin{tabular}{|l|r|r|r|r|r|}
\hline treatment & T CN & T CN (SD) & T CN NOS & T CN ANOVA & \multicolumn{2}{l|}{ T CN Mann } \\
Whitney
\end{tabular}

Table 2

Homogeneity: Normalized Deviation from the Nash Equilibrium (Index: CN: Normalized Deviation from the Nash Equlibrium data from gross and ordinary coverage samples insignificant)

\begin{tabular}{|l|r|r|r|r|r|}
\hline gross & NN & NN (SD) & NN NOS & NN ANOVA & $\begin{array}{l}\text { NN Mann- } \\
\text { Whitney }\end{array}$ \\
\hline homogeneous & 50,6590164 & 229,032508 & 305 & 0,098 & 0,492 \\
\hline heterogeneous & 8,65853659 & 21,4713243 & 82 & & \\
\hline treatment & T NN & T NN (SD) & T NN NOS & T NN ANOVA & \\
\hline homogeneous & 2,6 & 19,1911438 & 5 & 0,491 & 0,823 \\
\hline heterogeneous & 10,2352941 & 23,3433643 & 34 & & \\
\hline
\end{tabular}

Table 3

Homogeneity: Proportional Deviation from the Nash Equilibrium

(Legend: NN: Proportional Deviation from the Nash Equilibrium data from ordinary coverage sample insignificant)

A look at interaction effects clears the picture. When products are homogeneous, there is a certain positive deviation from the Nash expectation if subjects are rematched every round. If they have a fixed partner, the result is slightly below the Nash expectation. The pattern dramatically changes if products are heterogeneous. Now strangers end up far below the Nash expectation, whereas partners are somewhat above. If products are homogeneous, the distinction between simultaneous and sequential play has little effect on deviations from the Nash equilibrium. However with heterogeneity, in simultaneous interaction there is a small positive deviation from the Nash benchmark, whereas in sequential interaction the outcome is far below. If products are homogeneous and supply is constant, there is a small degree of collusion. If the supply curve has a positive slope, the deviation from the Nash equilibrium is negative. The pattern dramatically reverses if products are heterogeneous. Now subjects fall below the Nash expectation if gains from collusion are large. They end up high above the Nash benchmark if gains from collusion are small. 
If products are homogeneous and sellers are symmetric, there is less collusion than the Nash equilibrium predicts. The opposite is true when sellers are asymmetric. This totally changes if products are heterogeneous. Now seller symmetry yields a positive deviation from the Nash benchmark, whereas seller asymmetry pushes sellers far below the Nash prediction. Finally if products are homogeneous and capacity is unconstrained, sellers achieve a small surplus over the Nash expectation. The opposite is true if capacity is constrained. The picture reverses if products are heterogeneous. Now unconstrained capacity leads to a result below Nash, whereas constrained capacity induces subjects to collude at a level far above the Nash benchmark.

\begin{tabular}{|c|c|c|c|c|}
\hline partner/stranger & partner & partner (SD) & partner NOS & partner/stranger Sig. \\
\hline homogeneous & $-5,19548872$ & 83,8680868 & 266 & 0,05786161 \\
\hline \multirow[t]{2}{*}{ heterogeneous } & 3,04938272 & 65,5322251 & 81 & \\
\hline & stranger & stranger (SD) & stranger NOS & \\
\hline homogeneous & 11,7291667 & 35,5460382 & 48 & \\
\hline heterogeneous & $-36,5555556$ & 122,054405 & 9 & \\
\hline sequence & simultaneous & simultaneous (SD) & simultaneous NOS & sequence Sig. \\
\hline homogeneous & $-3,83773585$ & 83,4581646 & 265 & 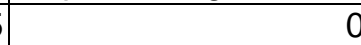 \\
\hline \multirow[t]{2}{*}{ heterogeneous } & 8,63095238 & 59,4431549 & 84 & \\
\hline & \begin{tabular}{|l|} 
sequential \\
\end{tabular} & sequential (SD) & sequential NOS & \\
\hline homogeneous & 4,04081633 & 44,1606722 & 49 & \\
\hline heterogeneous & $-134,5$ & 116,135696 & 6 & \\
\hline surplus & symmetric & symmetric (SD) & symmetric NOS & surplus Sig. \\
\hline homogeneous & $-4,9$ & 61,5540413 & 90 & 0,04078703 \\
\hline \multirow[t]{2}{*}{ heterogeneous } & 52 & 29,2711462 & 6 & \\
\hline & consumer & consumer (SD) & consumer NOS & \\
\hline homogeneous & $\begin{array}{r}6,39 \\
\end{array}$ & 50,5182976 & 200 & \\
\hline heterogeneous & $-4,69047619$ & 73,8901784 & 84 & \\
\hline symmetry & symmetric & symmetric (SD) & symmetric NOS & symmetry Sig. \\
\hline homogeneous & $-5,59911894$ & 89,9633288 & 227 & 0,00614978 \\
\hline \multirow[t]{2}{*}{ heterogeneous } & 13,2459016 & 40,4753652 & 61 & \\
\hline & asymmetric & asymmetric (SD) & asymmetric NOS & \\
\hline homogeneous & 5,1954023 & 33,8546273 & 87 & \\
\hline heterogeneous & $-30,6896552$ & 110,065598 & 29 & \\
\hline capacity & unconstrained & unconstrained (SD) & unconstrained NOS & capacity Sig. \\
\hline homogeneous & 5,79545455 & 48,9326439 & 176 & 0,00084469 \\
\hline \multirow[t]{2}{*}{ heterogeneous } & $-14,2769231$ & 80,5259096 & 65 & \\
\hline & constrained & constrained (SD) & constrained NOS & \\
\hline homogeneous & $-13,326087$ & 104,207203 & 138 & \\
\hline heterogeneous & 33,84 & 27,8652711 & 25 & \\
\hline
\end{tabular}

Table 4

Homogeneity: Interaction Effects

(normalized deviation from the Nash equilibrium) 


\section{Effect of Introducing Fixed Costs}

All three benchmarks for this study are taken from the one-shot situation. On the short run, for rational actors only marginal, and hence variable cost should matter. However, subjects interact over multiple rounds, and if there is a fixed cost it matters for the payment they expect from the experimenter. One should therefore expect that subjects trade at a price further away from the Walrasian equilibrium if there is a fixed cost. This expectation holds true in the data from the gross sample. In line with this, with no fixed cost, the normalised mean deviation from the Nash equilibrium is negative. If there is a fixed cost, the mean deviation becomes positive. Apparently, subjects do not decide in a purely forward-looking manner.

\begin{tabular}{|l|l|l|r|r|l|}
\hline gross & CW & CW (SD) & CW NOS & CW ANOVA & $\begin{array}{l}\text { CW Mann- } \\
\text { Whitney }\end{array}$ \\
\hline no fixed cost & 32,2363184 & 36,2569986 & 408 & 0 & 0 \\
\hline fixed cost & 58,4285714 & 53,5142452 & 102 & & \\
\hline
\end{tabular}

Table 5

Fixed Cost: Normalized Deviation from the Walrasian Equilibrium

(data on ordinary coverage insignificant; no treatment data available)

\begin{tabular}{|l|r|r|r|r|l|}
\hline gross & \multicolumn{1}{l|}{ CN } & CN (SD) & CN NOS & CN ANOVA & $\begin{array}{l}\text { CN Mann- } \\
\text { Whitney }\end{array}$ \\
\hline no fixed cost & $-6,76489028$ & 77,7691586 & 319 & 0,022 & 0 \\
\hline fixed cost & 14,7882353 & 73,6943647 & 85 & & \\
\hline
\end{tabular}

Table 6

Fixed Cost: Normalized Deviation from the Nash Equilibrium

(data on ordinary coverage insignificant; no treatment data available data on NN index from gross and ordinary coverage samples insignificant, from treatment sample not available)

\section{Effect of Constrained Capacity}

If sellers compete in price, if products are homogeneous, and if marginal cost is constant, the mere presence of a second seller suffices to force the competitive equilibrium on the sellers. This is in essence the result of (Bertrand 1883). In the literature, this result is typically referred to as the "Bertrand paradox" (e.g. Tirole 1988:210). Among the many attempts to dissolve the paradox, the first had been to introduce capacity constraints (Edgeworth 1897). Theory then expects positive profits. The experimental data stands in harsh opposition to the expectation. If capacity is constrained, collusion plummets with respect to all three indices. 


\begin{tabular}{|l|r|r|r|r|r|}
\hline gross & CW & CW (SD) & CW NOS & CW ANOVA & $\begin{array}{l}\text { CW Mann- } \\
\text { Whitney }\end{array}$ \\
\hline unconstrained & 54,0912698 & 38,9772076 & 252 & 0 & 0 \\
\hline constrained & 16,8590308 & 32,7397548 & 227 & & \\
\hline $\begin{array}{l}\text { ordinary cov- } \\
\text { erage }\end{array}$ & OC CW & OC CW (SD) & OC CW NOS & $\begin{array}{l}\text { OC CW ANO- } \\
\text { VA }\end{array}$ & \\
\hline unconstrained & 42,5 & 24,2806826 & 98 & & 0 \\
\hline constrained & 6,38607595 & 26,1501604 & 158 & & \\
\hline
\end{tabular}

Table 7

Capacity: Normalized Deviation from the Walrasian Equilibrium

(no treatment data available)

\begin{tabular}{|l|c|c|r|r|r|}
\hline gross & \multicolumn{1}{|l|}{ CN } & CN (SD) & CN NOS & CN ANOVA & $\begin{array}{l}\text { CN Mann- } \\
\text { Whitney }\end{array}$ \\
\hline unconstrained & 0,38174274 & 59,6220345 & 241 & 0,41 & 0,769 \\
\hline constrained & $-6,09202454$ & 97,9236166 & 163 & & \\
\hline $\begin{array}{l}\text { ordinary cov- } \\
\text { erage }\end{array}$ & OC CN & OC CN (SD) & OC CN NOS & $\begin{array}{l}\text { OC CN ANO- } \\
\text { VA }\end{array}$ & \\
\hline unconstrained & 5,64516129 & 33,9112157 & 93 & 0,028 & \\
\hline constrained & $-20,2340426$ & 107,531583 & 94 & & \\
\hline
\end{tabular}

Table 8

Capacity: Normalized Deviation from the Nash Equilibrium

(no treatment data available)

\begin{tabular}{|l|r|r|r|r|r|}
\hline gross & NN & NN (SD) & NN NOS & NN ANOVA & $\begin{array}{l}\text { NN Mann- } \\
\text { Whitney }\end{array}$ \\
\hline unconstrained & 58,1631799 & 252,777783 & 239 & 0,044 & 0,421 \\
\hline constrained & 15,2702703 & 70,1011509 & 148 & & \\
\hline $\begin{array}{l}\text { ordinary cov- } \\
\text { erage }\end{array}$ & OC NN & OC NN (SD) & OC NN NOS & OC NN ANO- & \\
\hline unconstrained & 130,43956 & 396,327031 & 91 & 0,004 & 0,001 \\
\hline constrained & 5,625 & 74,1055961 & 88 & & \\
\hline
\end{tabular}

Table 9

Capacity: Proportional Deviation from the Nash Equilibrium

(no treatment data available)

Interaction effects make it possible to say more about the underlying forces. Most graphic is the interaction with market size. In duopoly, the constraint only has a small (negative) effect on the deviation from the Walrasian equilibrium. The effect becomes a bit more pronounced in triopoly, and is strong in larger markets. In asymmetric markets, the negative effect of a capacity constraint on deviations from the Walrasian equilibrium is much more pronounced than in symmetric markets. Likewise, the negative effect is stronger in sequential than in simultaneous interaction. Collusion in homogeneous markets is dampened much more by a capacity constraint than when subjects trade in substitutes. Finally, a capacity constraint reduces collusion with all specifications of ex ante information, but the reduction is much stronger with reduced ex ante information. 


\begin{tabular}{|c|c|c|c|c|}
\hline size & size 2 & size $2(\mathrm{SD})$ & size 2 NOS & size Sig. \\
\hline unconstrained & 62,5733333 & 40,6232232 & 150 & 0,07080032 \\
\hline \multirow[t]{2}{*}{ constrained } & 59,1538462 & 22,3712842 & 13 & \\
\hline & size 3 & size $3(\mathrm{SD})$ & size 3 NOS & \\
\hline unconstrained & 48,8484848 & 32,913828 & 33 & \\
\hline \multirow[t]{2}{*}{ constrained } & 38,2826087 & 35,8029565 & 46 & \\
\hline & size 4 & size $4(\mathrm{SD})$ & size 4 NOS & \\
\hline unconstrained & 40,53125 & 36,5892496 & 32 & \\
\hline constrained & 7,04545455 & 28,6812237 & 110 & \\
\hline $\begin{array}{l}\text { ex ante informa- } \\
\text { tion }\end{array}$ & $\begin{array}{l}\text { reduced ex } \\
\text { ante }\end{array}$ & \begin{tabular}{|l|} 
reduced ex ante \\
(SD)
\end{tabular} & $\begin{array}{l}\text { reduced ex ante } \\
\text { NOS }\end{array}$ & ex ante Sig. \\
\hline unconstrained & 71,56 & 45,9547604 & 25 & 0 \\
\hline \multirow[t]{2}{*}{ constrained } & 7,20792079 & 25,3957937 & 101 & \\
\hline & partial ex ante & partial ex ante (SD) & partial ex ante NOS & \\
\hline unconstrained & 44,5 & 24,63737 & 52 & \\
\hline \multirow[t]{2}{*}{ constrained } & 29,6578947 & 38,2532643 & 38 & \\
\hline & full ex ante & full ex ante (SD) & full ex ante NOS & \\
\hline unconstrained & 57,738255 & 41,5450579 & 149 & \\
\hline constrained & 28,7741935 & 36,0820451 & 31 & \\
\hline symmetry & symmetry & symmetry (SD) & symmetry NOS & symmetry Sig. \\
\hline unconstrained & 50,345 & 40,3647437 & 200 & 0,00131709 \\
\hline \multirow[t]{2}{*}{ constrained } & 19,573913 & 36,7657499 & 115 & \\
\hline & asymmetry & asymmetry (SD) & asymmetry NOS & \\
\hline unconstrained & 68,5 & 29,2014638 & 52 & \\
\hline constrained & 14,0714286 & 27,90483 & 112 & \\
\hline homogeneity & homogeneous & homogeneous (SD) & homogeneous NOS & $\begin{array}{l}\text { homogeneity } \\
\text { Sig. }\end{array}$ \\
\hline unconstrained & 48,3903743 & 41,2493403 & 187 & \\
\hline \multirow[t]{2}{*}{ constrained } & 13,7 & 31,2028477 & 210 & 0 \\
\hline & heterogeneous & $\begin{array}{l}\text { heterogeneous } \\
\text { (SD) }\end{array}$ & heterogeneous NOS & \\
\hline unconstrained & 70,4923077 & 25,3975411 & 65 & \\
\hline constrained & 55,8823529 & 25,9540034 & 17 & \\
\hline
\end{tabular}

Table 10

Capacity: Interaction Effects

(deviations from the Walrasian equilibrium)

\section{Effect of Advance Production}

Theory expects a similar outcome if sellers ultimately compete in price, but have a chance to precommit on quantity. They then play a game of two stages that yields results similar to quantity competition, i.e. a price substantially above the expectation of the Bertrand model (Kreps and Scheinkman 1983; but see Davidson and Deneckere 1986). If subjects must produce a perishable commodity in advance, this is a way to implement the setting in the laboratory. Here, results are less impressive than with capacity constraints. The only result significant at the 5\% level is in the treatment sample, and with respect to the NN index. As with capacity constraints, however, collusion is reduced, not increased by the manipulation. Qualitatively, the treatment sample reaches the same result with respect to the CN index, but it is only weakly significant. 


\begin{tabular}{|c|c|c|c|c|c|}
\hline treatment & $\mathrm{TCW}$ & $\mathrm{T} \mathrm{CW}(\mathrm{SD})$ & T CW NOS & $\begin{array}{l}\text { T CW A- } \\
\text { NOVA }\end{array}$ & $\begin{array}{l}\text { T CW } \\
\text { Mann } \\
\text { Whitney }\end{array}$ \\
\hline $\begin{array}{l}\text { no advance produc- } \\
\text { tion }\end{array}$ & 42,3333333 & 26,5847701 & 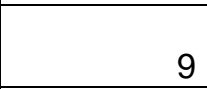 & 0,15124064 & 0,118 \\
\hline advance production & 22,75 & 31,7722721 & 12 & & \\
\hline
\end{tabular}

Table 11

Advance Production: Normalized Deviation from the Walrasian Equilibrium (data from gross and ordinary coverage samples insignificant)

\begin{tabular}{|l|r|l|r|l|l|}
\hline treatment & T CN & T CN (SD) & T CN NOS & T CN ANOVA & $\begin{array}{l}\text { T CN Mann } \\
\text { Whitney }\end{array}$ \\
\hline $\begin{array}{l}\text { no advance produc- } \\
\text { tion }\end{array}$ & 4 & 30,1454806 & 9 & 0,08337275 & 0,088 \\
\hline advance production & $-29,75$ & 48,6698058 & 12 & & \\
\hline
\end{tabular}

Table 12

Advance Production: Normalized Deviation from the Nash Equilibrium (all other data insignificant)

\begin{tabular}{|l|r|l|r|l|l|}
\hline treatment & T NN & T NN (SD) & T NN NOS & T NN ANOVA & $\begin{array}{l}\text { T NN Mann } \\
\text { Whitney }\end{array}$ \\
\hline $\begin{array}{l}\text { no advance produc- } \\
\text { tion }\end{array}$ & 3,66666667 & 8,51469318 & 9 & 0,04223725 & 0,025 \\
\hline advance production & $-5,25$ & 9,80839158 & 12 & & \\
\hline
\end{tabular}

Table 13

Advance Production: Proportional Deviation from the Nash Equilibrium

(all other data insignificant)

\section{Collusion when Process Innovation is Possible}

Do subjects collude more if they have a chance for a process innovation that reduces cost for them, but not for their competitors? There is no significant data with respect to the Nash equilibrium. With respect to the Walrasian equilibrium, the effect is significant and pronounced. The opportunity to invest in cost reduction leads to substantially more collusion. The fact that there is no significance in the sample reduced to experiments with ordinary coverage has a simple explanation. From 26 experiments with a chance to innovate only two are in the reduced sample.

\begin{tabular}{|l|l|l|r|r|r|}
\hline gross & CW & CW (SD) & CW NOS & CW ANOVA & $\begin{array}{l}\text { CW Mann- } \\
\text { Whitney }\end{array}$ \\
\hline no innovation & 34,9359823 & 36,5078226 & 453 & 0,001 & 0,159 \\
\hline innovation & 62,7692308 & 81,8873898 & 26 & & \\
\hline
\end{tabular}

Table 14

Innovation: Normalized Deviation from the Walrasian Equilibrium

(data from ordinary coverage sample insignificant, no treatment data on this index data on $\mathrm{CN}$ and $\mathrm{NN}$ indices insignificant, no treatment data on these indices) 


\section{Dependence of Collusion on Market Characteristics}

\section{Effect of Market Size}

Most independent variables in this data set are dichotomous or categorical. One of the major exceptions is market size. One may wonder whether, in a strict sense, this is a cardinal variable. But it at any rate is ordinal, which makes a linear regression meaningful. With respect to deviations from the Walrasian equilibrium, it is highly significant, and it has the expected result. The larger the market, the smaller the degree of collusion. With respect to deviations from the Nash equilibrium, only the $\mathrm{NN}$ index leads to a significant result, and only if one reduces the sample to experiments that explicitly tested for market size. The effect is also negative, but much less so than with the Walrasian equilibrium. In the treatment data, the effect of size on the CN index is even smaller, but still negative. This result, however, is not significant.

\begin{tabular}{|c|c|c|c|c|}
\hline gross & CW B & CW B SD & CW Beta & CW Sig. \\
\hline & $-4,42037497$ & 0,61463467 & $-0,31277205$ & 0 \\
\hline & CW Const & \multicolumn{2}{|l|}{ CW Const SD } & CW Const Sig \\
\hline & 53,7129887 & 2,97988296 & & 0 \\
\hline & CW R^2 & $C W$ adj. $R^{\wedge} 2$ & & \\
\hline & 0,09782636 & 0,09593501 & & \\
\hline \multirow[t]{6}{*}{ ordinary coverage } & OC CW B & OC CW B SD & OC CW Beta & OC CW Sig. \\
\hline & $-2,19592089$ & \begin{tabular}{|l|}
0,53092697 \\
\end{tabular} & $-0,2511955$ & 0 \\
\hline & $\begin{array}{l}\text { OC CW } \\
\text { Const }\end{array}$ & \multicolumn{2}{|l|}{ OC CW Const SD } & OC CW Const Sig \\
\hline & 30,5386279 & 3,12131327 & & 0 \\
\hline & OC CW R^2 & \multicolumn{2}{|l|}{ OC CW adj. $R^{\wedge} 2$} & \\
\hline & 0,063 & 0,059 & & \\
\hline \multirow[t]{6}{*}{ treatment } & T CW B & T CW B SD & T CW Beta & T CW Sig. \\
\hline & $-4,40960208$ & 1,08323964 & $-0,35091268$ & 0 \\
\hline & T CW Const & \multicolumn{2}{|l|}{ T CW Const SD } & T CW Const Sig \\
\hline & 59,636808 & \begin{tabular}{|l|}
4,9777975 \\
\end{tabular} & & 0 \\
\hline & $\mathrm{TCW} \mathrm{R}^{\wedge} 2$ & \multicolumn{2}{|l|}{ T CW adj.R^2 } & \\
\hline & 0,123 & 0,116 & & \\
\hline
\end{tabular}

Table 15

Market Size

Normalized Deviation from the Walrasian Equilibrium: Regression

(Legend: CW: Normalized Deviation from the Walrasian Equilibrium

SD: Standard Deviation

NOS: Numbers of Observations

B: B Value

Beta: normalized B Value

Sig: Significance Level

Const: Constante

$\mathrm{R}^{\wedge} 2$ : $\mathrm{R}$ Square

adj. $R^{\wedge} 2$ : adjusted $R$ Square

OC: sample reduced to experiments with Ordinary Coverage

$\mathrm{T}$ : sample reduced to experiments where homogeneity was a Treatment variable) 


\begin{tabular}{|l|l|c|c|r|}
\hline treatment & T CN B & T CN B SD & T CN Beta & T CN Sig. \\
\hline & $-2,40376305$ & 2,5122409 & $-0,09386209$ & 0,34089841 \\
\hline & T CN Const & T CN Const SD & & T CN Const Sig \\
\hline & 17,3645249 & 11,5099233 & & 0,13444788 \\
\hline & T CN R^2 & T CN adj.R^2 & & \\
\hline
\end{tabular}

Table 16

Market Size

Normalized Deviation from the Nash Equilibrium: Regression

(Legend: CN: Proportional Deviation from the Nash Equilibrium

data from the gross and ordinary coverage samples insignificant)

\begin{tabular}{|r|l|c|c|r|}
\hline treatment & T NN B & T NN B SD & T NN Beta & T NN Sig. \\
\hline & $-4,98615508$ & 2,57577325 & $-0,19480297$ & 0,05586649 \\
\hline & T NN Const & T NN Const SD & & T NN Const Sig \\
\hline & 52,5256509 & 11,9103942 & & 0 \\
\hline & T NN R^2 & T NN adj.R^2 & & \\
\hline & 0,0379482 & 0,02782134 & & \\
\hline
\end{tabular}

Table 17

Market Size

Proportional Deviation from the Nash Equilibrium: Regression

(Legend: NN: Proportional Deviation from the Nash Equlibrium

all regressions on $\mathrm{CN}$ index, and regressions on NN index based on gross and ordinary coverage sam-

ples insignificant)

"Four are few, and six are many”, game theorists say (Selten 1973). “Two are few, and four are many”, experimentalists claim (Huck, Normann et al. 2004). It therefore makes sense to also look at outcomes for individual market sizes. If one looks at the gross data, and at the deviation from the Walrasian equilibrium, theory seems to get it right. While the degree of collusion in quadropoly is much smaller than in triopoly, it again goes up to almost the level of triopoly in a market of five. In markets of 6,7 and 8, the deviation is much smaller. However, the picture is far from clear. In markets of 10 and 16, the deviation is again remarkable.

The CN index supports the experimentalist view. There is a positive deviation in duopoly and triopoly, and a negative deviation in markets of 4 and 5. However, that finding too is not totally beyond doubt. There are small positive deviations from the Nash prediction in markets of 10 and 22. 


\begin{tabular}{|l|r|l|r|l|l|}
\hline & CW & CW (SD) & CW NOS & $\begin{array}{l}\text { CW ANO- } \\
\text { VA }\end{array}$ & $\begin{array}{l}\text { CW } \\
\text { Kruskal- } \\
\text { Wallis }\end{array}$ \\
\hline size 2 & 62,3006135 & 39,4430571 & 163 & 0 & \\
\hline size 3 & 42,6962025 & 34,8061866 & 79 & & \\
\hline size 4 & 14,5915493 & 33,5766626 & 142 & & \\
\hline size 5 & 37,95 & 30,7989662 & 20 & & \\
\hline size 6 & 18,0540541 & 28,2527737 & 37 & & \\
\hline size 7 & 1 & 13,7840488 & 6 & & \\
\hline size 8 & 14,9473684 & 25,9325486 & 19 & & \\
\hline size 10 & 26 & & 1 & & \\
\hline size 11 & 8,5 & 1,73205081 & 4 & & \\
\hline size 16 & 38 & 32,5269119 & 2 & & \\
\hline size 22 & 6,75 & 29,0789156 & 4 & & \\
\hline size 25 & -11 & 14,1421356 & 2 & & \\
\hline
\end{tabular}

Table 18

Individual Market Size

Normalized Deviation from the Walrasian Equilibrium

(gross data only; ordinary coverage data and treatment data is also significant at the 0,000 level, and shows the same qualitative picture)

\begin{tabular}{|l|r|l|r|r|l|}
\hline & & & & & $\begin{array}{l}\text { NN } \\
\text { Kruskal- } \\
\text { Wallis }\end{array}$ \\
\hline size 2 & NN & NN (SD) & NN NOS & NN ANOVA & 0,003 \\
\hline size 3 & 65,8636364 & 143,836438 & 158 & 0,021 & \\
\hline size 4 & 26,53 & 160,645004 & 100 & & \\
\hline size 5 & $-4,3125$ & 12,3758838 & 16 & & \\
\hline size 6 & 260,4375 & 620,428881 & 16 & & \\
\hline size 7 & $-13,6666667$ & 13,2035349 & 3 & & \\
\hline size 8 & 11,7333333 & 21,7139411 & 15 & & \\
\hline size 10 & 2 & & 1 & & \\
\hline size 11 & $-3,5$ & 1,91485422 & 4 & & \\
\hline size 16 & -6 & 0 & 2 & & \\
\hline size 22 & $-0,25$ & 2,21735578 & 4 & & \\
\hline size 25 & -6 & 4,24264069 & 2 & & \\
\hline
\end{tabular}

Table 19

Individual Market Size

Proportional Deviation from the Nash Equilibrium

(gross data only; $\mathrm{CN}$ index is insignificant) 


\section{Symmetry vs. Asymmetry of Sellers}

In the view of antitrust authorities, when assessing the opportunities for tacit collusion, symmetry is a crucial factor. ${ }^{9}$ The experimental evidence is more nuanced. This might be due to the fact that symmetry facilitates imitation, which increases competitive pressure. In the gross sample, asymmetry has little effect on the deviation from the Walrasian equilibrium. It is stronger if one reduces the sample to experiments with ordinary coverage, but it almost disappears in those experiments that explicitly tested for symmetry (and is not significant). The deviation from the Nash equilibrium is much clearer, and in line with what antitrust authorities think. But it is (in ordinary coverage only weakly) significant only with respect to the NN index. The CN index is weakly significant only for the experiments that had symmetry as a treatment variable.

\begin{tabular}{|l|l|l|r|r|r|}
\hline gross & CW & CW (SD) & CW NOS & CW ANOVA & $\begin{array}{l}\text { CW Mann- } \\
\text { Whitney }\end{array}$ \\
\hline symmetry & 39,1111111 & 41,7554722 & 315 & 0,0465909 & 0,015 \\
\hline asymmetry & 31,3292683 & 37,9801546 & 164 & & \\
\hline $\begin{array}{l}\text { ordinary cover- } \\
\text { age }\end{array}$ & OC CW & $\begin{array}{l}\text { OC CW } \\
\text { (SD) }\end{array}$ & $\begin{array}{l}\text { OC CW } \\
\text { NOS }\end{array}$ & $\begin{array}{l}\text { OC CW ANO- } \\
\text { VA }\end{array}$ \\
\hline symmetry & 27,2484472 & 32,8722967 & 161 & & \\
\hline asymmetry & 8,28421053 & 22,8434371 & 95 & & \\
\hline treatment & T CW & T CW (SD) & T CW NOS & T CW ANOVA & \\
\hline symmetry & 72,2222222 & 25,1713085 & 18 & 0,90811584 & 0,752 \\
\hline asymmetry & 71,2631579 & 30,4681351 & 38 & & \\
\hline
\end{tabular}

Table 20

Symmetry: Normalized Deviation from the Walrasian Equilibrium

\begin{tabular}{|l|l|l|r|r|l|}
\hline treatment & T CN & T CN (SD) & T CN NOS & T CN ANOVA & $\begin{array}{l}\text { T CN Mann } \\
\text { Whitney }\end{array}$ \\
\hline symmetry & 18,7727273 & 68,5405211 & 22 & 0,09588123 & 0,047 \\
\hline & - & & & \\
asymmetry & 19,5476191 & 93,8460604 & 42 & & \\
\hline
\end{tabular}

Table 21

Symmetry: Normalized Deviation from the Nash Equilibrium

(data from gross and ordinary coverage samples insignificant)

9 Department of Justice, Federal Trade Commission, Antitrust Division, 1992 Horizontal Merger Guidelines of September 10, 1992, 57 FR 41552, Section 2.11; ECJ of First Instance Case T-102/96, Gencor v Commission, [1999] ECR II-753, paragraph 222; EC Commission Decision 92/553/EC in Case IV/M.190 Nestlé/Perrier, OJ L 356, 5.12.1992, p. 1, points 63-123. 


\begin{tabular}{|l|l|l|r|r|r|}
\hline gross & NN & NN (SD) & NN NOS & NN ANOVA & $\begin{array}{l}\text { NN Mann- } \\
\text { Whitney }\end{array}$ \\
\hline symmetry & 55,3498233 & 236,903865 & 283 & 0,03062506 & 0,026 \\
\hline asymmetry & 4,77884615 & 27,2756361 & 104 & & \\
\hline ordinary coverage & OC NN & OC NN (SD) & OC NN NOS & OC NN ANOVA & \\
\hline symmetry & 92,4592593 & 334,671632 & 135 & 0,06154268 & 0,002 \\
\hline asymmetry & $-2,65909091$ & 7,72173972 & 44 & & \\
\hline treatment & T NN & T NN (SD) & T NN NOS & T NN ANOVA & \\
\hline symmetry & 44,3888889 & 79,4859506 & 18 & 0,02969758 & \\
\hline asymmetry & 8,81578947 & 40,2511408 & 38 & & \\
\hline
\end{tabular}

Table 22

Symmetry: Proportional Deviation from the Nash Equilibrium

Again, interaction effects help to understand the somewhat mixed evidence. It is particularly interesting to test for interactions with market size. Asymmetry increases collusion in markets of 2 and 3, but reduces it in larger markets. Moreover, symmetry hurts if gains from collusion are small, but it helps if there is a larger pie.

\begin{tabular}{|c|c|c|c|c|}
\hline size & size 2 & size $2(\mathrm{SD})$ & size 2 NOS & size Sig. \\
\hline symmetry & 59,3082707 & 42,1597216 & 133 & 0,00060183 \\
\hline \multirow[t]{2}{*}{ asymmetry } & 75,5666667 & 19,4221405 & 30 & \\
\hline & size 3 & size $3(\mathrm{SD})$ & size 3 NOS & \\
\hline symmetry & 33,4418605 & 29,2023338 & 43 & \\
\hline \multirow[t]{2}{*}{ asymmetry } & 53,75 & 38,0213286 & 36 & \\
\hline & size 4 & size $4(\mathrm{SD})$ & size 4 NOS & \\
\hline symmetry & 18,626506 & 37,6708177 & 83 & \\
\hline \multirow[t]{2}{*}{ asymmetry } & 8,91525424 & 26,0452445 & 59 & \\
\hline & size 5 & size 5 (SD) & size 5 NOS & \\
\hline symmetry & 51 & $\begin{array}{r}33,4932829 \\
\end{array}$ & 11 & \\
\hline asymmetry & 22 & 18,1727818 & 9 & \\
\hline surplus & producer surplus & producer surplus (SD) & producer surplus NOS & surplus Sig. \\
\hline symmetry & $-18,375$ & 38,9539563 & 8 & 0,00137745 \\
\hline \multirow[t]{2}{*}{ asymmetry } & 25,1176471 & 30,7284118 & 17 & \\
\hline & symmetric surplus & symmetric surplus (SD) & symmetric surplus NOS & \\
\hline symmetry & 27,6981132 & 33,1364193 & 106 & \\
\hline \multirow[t]{2}{*}{ asymmetry } & 3,34615385 & 17,7153996 & 26 & \\
\hline & consumer surplus & consumer surplus (SD) & consumer surplus NOS & \\
\hline symmetry & 48,5103093 & 43,0939737 & 194 & \\
\hline asymmetry & 38,214876 & 39,3086518 & 121 & \\
\hline
\end{tabular}

Table 23

Symmetry: Interaction Effects

(normalized deviation from the Walrasian equilibrium) 


\section{3. fect of Power Asymmetries among Sellers}

Symmetry addresses relative gains from collusion, whereas power says something about bargaining weights when it comes to (implicit) negotiations about how to split these gains. In experiments, power is typically implemented by giving some, but not all sellers inframarginal units. These sellers then can exert influence on their competitors by withholding supply. ${ }^{10}$

The effect of power on deviations from the Walrasian equilibrium is insignificant throughout, as is the effect on proportional deviations from the Nash equilibrium. However, the effect on the $\mathrm{CN}$ index is highly significant. The effect is not surprising. If some sellers have power, this pushes the equilibrium far below the Nash prediction.

\begin{tabular}{|l|l|l|r|r|l|}
\hline treatment & T CW & T CW (SD) & T CW NOS & T CW ANOVA & $\begin{array}{l}\text { T CW Mann } \\
\text { Whitney }\end{array}$ \\
\hline no power & 56,8571429 & 28,3162413 & 7 & 0,13489024 & 0,241 \\
\hline power & 71,8461539 & 14,9935884 & 13 & & \\
\hline
\end{tabular}

Table 24

Power: Normalized Deviation from the Walrasian Equilibrium

(data from the gross and ordinary coverage samples insignificant)

\begin{tabular}{|l|c|c|r|r|r|}
\hline gross & CN & CN (SD) & CN NOS & CN ANOVA & $\begin{array}{l}\text { CN Mann- } \\
\text { Whitney }\end{array}$ \\
\hline no power & 4,58933333 & 49,6103738 & 375 & 0 & 0,023 \\
\hline power & $-90,4137931$ & 211,052552 & 29 & & \\
\hline ordinary coverage & OC CN & OC CN (SD) & OC CN NOS & OC CN ANOVA & \\
\hline no power & $-0,62857143$ & 32,9936303 & 175 & 0 & 0,363 \\
\hline power & $-105,583333$ & 285,93593 & 12 & & \\
\hline treatment & $\mathrm{T} \mathrm{CN}$ & T CN (SD) & T CN NOS & T CN ANOVA & \\
\hline no power & 18,2857143 & 21,2423656 & 7 & 0,21427761 & 0,485 \\
\hline power & $-38,8461539$ & 114,962201 & 13 & & \\
\hline
\end{tabular}

Table 25

Power: Normalized Deviation from the Nash Equilibrium

\begin{tabular}{|l|l|l|r|r|l|}
\hline treatment & T NN & T NN (SD) & T NN NOS & T NN ANOVA & $\begin{array}{l}\text { T NN Mann } \\
\text { Whitney }\end{array}$ \\
\hline no power & 5,57142857 & 5,38074167 & 7 & 0,77904285 & 0,485 \\
\hline power & 4,30769231 & 10,9497688 & 13 & & \\
\hline
\end{tabular}

Table 26

Power: Proportional Deviation from the Nash Equilibrium

(data from the gross and ordinary coverage samples insignificant)

10 Of course, this also generate asymmetry among sellers. But asymmetry is the wider category. It in particular also covers mere cost asymmetry. 


\section{Dependence of Collusion on Demand and Supply Characteristics}

\section{Effect of Demand Characteristics}

From a theoretical perspective, the shape of the demand curve matters since it is the upper bound of the bargaining range. Most experiments use a linear demand curve with negative slope. Frequently, there is also a step function that could be approximated by such a linear curve. Occasionally more complicated, e.g. quadratic, specifications are used. All this is presented here as demand decreasing in quantity. It is opposed to constant demand. In such a box design, it would in principle be possible for the sellers to appropriate the entire consumer rent.

The effect of this manipulation on the deviation from the Walrasian equilibrium is significant only if one reduces the sample to experiments with ordinary coverage. It has the expected direction. Collusion is much higher if demand is constant. Likewise, the mean deviation from the Nash equilibrium is negative, both measured by the CN and the NN index, if demand decreases in quantity. It is positive with constant demand.

\begin{tabular}{|l|r|r|r|r|r|}
\hline $\begin{array}{l}\text { ordinary } \\
\text { coverage }\end{array}$ & OC CW & OC CW (SD) & OC CW NOS & $\begin{array}{l}\text { OC CW } \\
\text { ANOVA }\end{array}$ & $\begin{array}{l}\text { OC CW Mann } \\
\text { Whitney }\end{array}$ \\
\hline constant demand & 38,8979592 & 22,79825 & 49 & 0 & 0 \\
\hline decreasing demand & 15,4852941 & 31,0628598 & 204 & & \\
\hline
\end{tabular}

Table 27

Demand: Normalized Deviation from the Walrasian Equilibrium

(data from the gross sample insignificant, no treatment data available)

\begin{tabular}{|l|r|r|r|l|l|}
\hline ordinary coverage & OC CN & OC CN (SD) & OC CN NOS & $\begin{array}{l}\text { OC CN ANO- } \\
\text { VA }\end{array}$ & $\begin{array}{l}\text { OC CN Mann } \\
\text { Whitney }\end{array}$ \\
\hline constant demand & 20,6818182 & 19,0321304 & 44 & 0,00672669 & 0 \\
\hline decreasing demand & $-17,1214286$ & 90,6806768 & 140 & & \\
\hline
\end{tabular}

Table 28

Demand: Normalized Deviation from the Nash Equilibrium

(data from the gross sample insignificant, no treatment data available)

\begin{tabular}{|l|l|l|r|r|r|}
\hline gross & NN & NN (SD) & NN NOS & NN ANOVA & $\begin{array}{l}\text { NN Mann- } \\
\text { Whitney }\end{array}$ \\
\hline constant demand & 234,923077 & 501,455953 & 52 & 0 & 0 \\
\hline decreasing demand & 11,9329268 & 56,1681215 & 328 & & \\
\hline ordinary coverage & OC NN & OC NN (SD) & OC NN NOS & OC NN ANOVA & \\
\hline constant demand & 288,214286 & 545,357101 & 42 & 0 & \\
\hline decreasing demand & 1,74626866 & 60,2104938 & 134 & & \\
\hline
\end{tabular}

Table 29

Demand: Proportional Deviation from the Nash Equilibrium

(no treatment data available) 


\section{Effect of Supply Characteristics}

In practice, supply curves often have negative slope. There are, however, no experiments that have tested such a market. In most experiments, marginal cost and hence supply is constant. In many others, marginal cost increases in quantity, meaning that supply decreases in quantity. From a theoretical perspective, the supply curve is the lower bound of the bargaining range. If supply decreases in quantity, sellers have less to gain from collusion. This expectation is borne out by all data in all samples and with respect to all indices.

\begin{tabular}{|l|c|c|r|r|r|}
\hline gross & CW & CW (SD) & CW NOS & CW ANOVA & $\begin{array}{l}\text { CW Mann- } \\
\text { Whitney }\end{array}$ \\
\hline constant supply & 53,4411765 & 39,2385579 & 272 & 0 & 0 \\
\hline decreasing supply & 14,01 & 30,7082216 & 200 & & \\
\hline ordinary coverage & OC CW & OC CW (SD) & OC CW NOS & $\begin{array}{l}\text { OC CW A- } \\
\text { NOVA }\end{array}$ \\
\hline constant supply & 42,4680851 & 23,9787998 & 94 & 0 & 0 \\
\hline decreasing supply & 6,74842767 & 26,8179443 & 159 & & \\
\hline treatment & T CW & T CW (SD) & T CW NOS & T CW ANO- & \\
\hline constant supply & 72,3333333 & 19,8051111 & 12 & & 0 \\
\hline decreasing supply & 17,1785714 & 39,1086365 & 28 & & \\
\hline
\end{tabular}

Table 30

Supply: Normalized Deviation from the Walrasian Equilibrium

\begin{tabular}{|l|c|c|r|r|r|}
\hline ordinary coverage & OC CN & OC CN (SD) & OC CN NOS & $\begin{array}{l}\text { OC CN A- } \\
\text { NOVA }\end{array}$ & $\begin{array}{l}\text { CN Mann } \\
\text { Whitney }\end{array}$ \\
\hline constant supply & 8,23595506 & 26,2877531 & 89 & 0,00797099 & 0 \\
\hline decreasing supply & $-23,3684211$ & 108,161823 & 95 & & \\
\hline treatment & T CN & T CN (SD) & T CN NOS & T CN ANOVA & \\
\hline constant supply & \multicolumn{1}{|c|}{59,0833333} & 36,807752 & 12 & 0 & 0 \\
\hline decreasing supply & $-3,16666667$ & 30,6483854 & 18 & & \\
\hline
\end{tabular}

Table 31

Supply: Normalized Deviation from the Nash Equilibrium

(data from the gross sample insignificant)

\begin{tabular}{|l|l|l|r|r|r|}
\hline gross & NN & NN (SD) & NN NOS & NN ANOVA & $\begin{array}{l}\text { NN Mann- } \\
\text { Whitney }\end{array}$ \\
\hline constant supply & 59,3474904 & 243,925716 & 259 & 0,01911447 & 0 \\
\hline decreasing supply & 6,27272727 & 64,8458428 & 121 & & \\
\hline ordinary coverage & OC NN & OC NN (SD) & OC NN NOS & OC NN ANOVA & \\
\hline constant supply & 137,103448 & 404,165089 & 87 & 0,0027215 & 0 \\
\hline decreasing supply & 4,61797753 & 73,8609728 & 89 & & \\
\hline treatment & T NN & T NN (SD) & T NN NOS & T NN ANOVA & \\
\hline constant supply & 944 & 100,08451 & 12 & 0,00063051 & \\
\hline decreasing supply & 2,72222222 & 13,813061 & 18 & & \\
\hline
\end{tabular}

Table 32

Supply: Proportional Deviation from the Nash Equilibrium 


\section{Dependence of Collusion on the Distribution of the Surplus}

While demand and supply say something about the upper and lower bound of the bargaining range, surplus directly measures how much sellers have to gain from collusion. If most of the surplus is with producers anyhow, gains from collusion are small. If, in the Walrasian equilibrium, the distribution of the surplus is symmetric, collusion pays more. It is most profitable if, under perfect competition, most of the surplus would go to consumers. As the data shows, subjects are highly sensitive to this with respect to all three indices. The treatment data is insignificant, which is probably due to small sample size. It however consistently points into the same direction.

\begin{tabular}{|c|c|c|c|c|c|}
\hline gross & $\mathrm{CW}$ & $\mathrm{CW}(\mathrm{SD})$ & CW NOS & CW ANOVA & $\begin{array}{l}\text { CW Kruskal- } \\
\text { Wallis }\end{array}$ \\
\hline producer surplus & 11,2 & 38,7405903 & 25 & 0 & 0 \\
\hline symmetric surplus & 22,9015152 & 32,1636701 & 132 & & \\
\hline consumer surplus & 44,5555556 & 41,9180949 & 315 & & \\
\hline $\begin{array}{l}\text { ordinary cover- } \\
\text { age }\end{array}$ & $\mathrm{OCCW}$ & OC CW (SD) & OC CW NOS & OC CW ANOVA & \\
\hline producer surplus & 0,55 & 35,0690672 & 20 & 0,00358389 & 0,008 \\
\hline symmetric surplus & 18,0485437 & 32,0873131 & 103 & & \\
\hline consumer surplus & 24,5769231 & 28,313545 & 130 & & \\
\hline treatment & T CW & $\mathrm{T} \mathrm{CW}(\mathrm{SD})$ & T CW NOS & T CW ANOVA & \\
\hline producer surplus & $-0,64285714$ & 36,6639776 & 14 & 0,85851372 & 0,865 \\
\hline symmetric surplus & 2,5 & 16,2326831 & 6 & & \\
\hline consumer surplus & 4,27586207 & 23,5719212 & 29 & & \\
\hline
\end{tabular}

Table 33

Surplus: Normalized Deviation from the Walrasian Equilibrium

\begin{tabular}{|l|r|r|r|r|r|}
\hline gross & CN & CN (SD) & CN NOS & CN ANOVA & $\begin{array}{l}\text { CN Kruskal- } \\
\text { Wallis }\end{array}$ \\
\hline producer surplus & $-84,0952381$ & 215,527702 & 21 & & 0,003 \\
\hline symmetric surplus & $-1,34375$ & 61,5337012 & 96 & & \\
\hline consumer surplus & \multicolumn{1}{|l|}{3,11267606} & 58,4937674 & 284 & & \\
\hline ordinary coverage & OC CN & OC CN (SD) & OC CN NOS & OC CN ANOVA & \\
\hline producer surplus & $-113,5625$ & 240,771252 & 16 & & \\
\hline symmetric surplus & 8,23287671 & 25,4288335 & 73 & & \\
\hline consumer surplus & $-2,85263158$ & 30,9852293 & 95 & & \\
\hline treatment & T CN & T CN (SD) & T CN NOS & T CN ANOVA & \\
\hline producer surplus & $-141,454546$ & 288,010196 & 11 & 0,29050078 & 0,034 \\
\hline symmetric surplus & 2,5 & 16,2326831 & 6 & & \\
\hline consumer surplus & 4,8 & 18,8069136 & 5 & & \\
\hline
\end{tabular}

Table 34

Surplus: Normalized Deviation from the Nash Equilibrium 


\begin{tabular}{|l|r|c|r|r|r|}
\hline gross & NN & NN (SD) & NN NOS & NN ANOVA & $\begin{array}{l}\text { NN Kruskal- } \\
\text { Wallis }\end{array}$ \\
\hline producer surplus & $-26,0476191$ & 53,5504213 & 21 & 0 & 0 \\
\hline symmetric surplus & 158,071429 & 410,884054 & 84 & & \\
\hline consumer surplus & \multicolumn{1}{|c|}{12,36} & 44,7012533 & 275 & & \\
\hline ordinary coverage & OC NN & OC NN (SD) & OC NN NOS & OC NN ANOVA & \\
\hline producer surplus & $-34,9375$ & 58,8687452 & 16 & 0 & \\
\hline symmetric surplus & 199,030769 & 459,373281 & 65 & & \\
\hline consumer surplus & $-0,41052632$ & 11,9764794 & 95 & & 0,083 \\
\hline treatment & T NN & T NN (SD) & T NN NOS & T NN ANOVA & \\
\hline producer surplus & -48 & 67,690472 & 11 & 0,10540691 & \\
\hline symmetric surplus & -1 & 5,65685425 & 6 & & \\
\hline consumer surplus & $-0,4$ & 2,07364414 & 5 & & \\
\hline
\end{tabular}

Table 35

Surplus: Proportional Deviation from the Nash Equilibrium

\section{Dependence of Collusion on Seller Characteristics}

One of the standard defences of the rational choice approach is this: well yes, not everybody behaves like homo oeconomicus. But if you give them some chance to practise, they will (cf. e.g. Friedman 1953). The experimental evidence is at best mixed. If measured against the Walrasian equilibrium, experienced subjects collude less. This may be read as evidence for the learning expectation. But if one compares behaviour to the Nash equilibrium, experienced subjects collude substantially more. Apparently, they learn to collude, not to play Nash. One might object that the benchmark is taken from one shot interaction. In line with the folk theorem, collusion is an equilibrium in the repeated game with uncertain duration (Aumann and Shapley 1994). If that were the reason, however, one would have to see a strong interaction effect with the treatment variable partner versus stranger design. This is not the case. Both with the CN and the NN index, the interaction effect is insignificant ( $\mathrm{p}=0,933$ in both cases).

\begin{tabular}{|l|l|l|r|r|r|}
\hline gross & CW & CW (SD) & CW NOS & CW ANOVA & $\begin{array}{l}\text { CW Mann- } \\
\text { Whitney }\end{array}$ \\
\hline no experience & 38,1138614 & 41,3056982 & 404 & 0,03701152 & 0,022 \\
\hline experience & 27,4666667 & 35,7106742 & 75 & & \\
\hline treatment & T CW & T CW (SD) & T CW NOS & T CW ANOVA & \\
\hline no experience & 26,9122807 & 38,9960074 & 57 & 0,61063109 & 0,735 \\
\hline experience & 30,6981132 & 38,695351 & 53 & & \\
\hline
\end{tabular}

Table 36

Experience: Normalized Deviation from the Walrasian Equilibrium

(data from the ordinary coverage sample insignificant) 


\begin{tabular}{|l|l|l|r|r|r|}
\hline gross & CN & CN (SD) & CN NOS & CN ANOVA & $\begin{array}{l}\text { CN Mann- } \\
\text { Whitney }\end{array}$ \\
\hline no experience & $-4,85344828$ & 81,6491321 & 348 & 0,08925335 & 0,059 \\
\hline experience & 14,0714286 & 38,1546409 & 56 & & \\
\hline treatment & T CN & T CN (SD) & T CN NOS & T CN ANOVA & \\
\hline no experience & 4,825 & 53,2184118 & 40 & 0,26124052 & 0,475 \\
\hline experience & 17,2972973 & 42,341774 & 37 & & \\
\hline
\end{tabular}

Table 37

Experience: Normalized Deviation from the Nash Equilibrium

(data from the ordinary coverage sample insignificant)

\begin{tabular}{|l|r|r|r|r|r|}
\hline gross & \multicolumn{1}{|l|}{ NN } & NN (SD) & NN NOS & NN ANOVA & $\begin{array}{l}\text { NN Mann- } \\
\text { Whitney }\end{array}$ \\
\hline no experience & \multicolumn{1}{|c|}{32,505988} & 178,492835 & 334 & 0,02504473 & 0,005 \\
\hline experience & 100,075472 & 318,645502 & 53 & & \\
\hline ordinary coverage & \multicolumn{1}{|c|}{ OC NN } & OC NN (SD) & OC NN NOS & OC NN ANOVA & \\
\hline no experience & 51,5324675 & 256,367031 & 154 & 0,04667632 & 0,115 \\
\hline experience & 177,16 & 452,596737 & 25 & & \\
\hline treatment & \multicolumn{1}{|c|}{ T NN } & T NN (SD) & T NN NOS & T NN ANOVA & \\
\hline no experience & 27,55 & 63,2114685 & 40 & 0,85198341 & 0,527 \\
\hline experience & 25,1081081 & 49,8240146 & 37 & & \\
\hline
\end{tabular}

Table 38

Experience: Proportional Deviation from the Nash Equilibrium

\section{Role of Seller Interaction in Explaining Collusion}

\section{Dependence on the Strategic Variable}

If sellers compete in price, if the product is homogeneous, and if marginal cost is constant, the Bertrand model expects the competitive equilibrium (Bertrand 1883). If they compete in quantity, a deviation from the Walrasian equilibrium is expected, the larger the smaller the market (Cournot 1838). These expectations are only partly borne out by the experimental evidence. There is indeed a larger deviation from the competitive equilibrium if quantity is the strategic variable. If they compete in quantity, sellers end up close to or even below the Nash equilibrium. But if they compete in price, the market outcome is high above the Nash prediction. 


\begin{tabular}{|l|c|c|r|r|r|}
\hline gross & CW & CW (SD) & CW NOS & CW ANOVA & $\begin{array}{l}\text { CW Mann- } \\
\text { Whitney }\end{array}$ \\
\hline quantity & 49,4251969 & 31,1895179 & 127 & 0 & 0 \\
\hline price & 30,3579882 & 36,7079129 & 338 & & \\
\hline ordinary coverage & OC CW & OC CW (SD) & OC CW NOS & OC CW ANOVA & \\
\hline quantity & 37,9090909 & 26,4599901 & 44 & 0 & 0 \\
\hline price & 16,6220096 & 30,7376569 & 209 & & \\
\hline treatment & T CW & T CW (SD) & T CW NOS & T CW ANOVA & \\
\hline quantity & 57,7619048 & 23,5688455 & 21 & 0,48151018 & 0,743 \\
\hline price & 51,3636364 & 34,2463699 & 22 & & \\
\hline
\end{tabular}

Table 39

Strategic Variable: Normalized Deviation from the Walrasian Equilibrium

\begin{tabular}{|l|r|r|r|r|r|}
\hline treatment & \multicolumn{1}{|c|}{ T CN } & T CN (SD) & T CN NOS & T CN ANOVA & \multicolumn{2}{|l|}{ W CN Mann } \\
\hline quantity & $-21,952381$ & 56,2463121 & 21 & 0,00856131 & 0,006 \\
\hline price & 18,1818182 & 37,6369074 & 22 & & \\
\hline
\end{tabular}

Table 40

Strategic Variable: Normalized Deviation from the Nash Equilibrium

(data from the gross and the ordinary coverage samples insignificant)

\begin{tabular}{|l|l|l|r|r|r|}
\hline gross & NN & NN (SD) & NN NOS & NN ANOVA & $\begin{array}{l}\text { NN Mann- } \\
\text { Whitney }\end{array}$ \\
\hline quantity & $-1,2519685$ & 16,2529453 & 127 & 0,00321872 & \\
\hline price & \multicolumn{1}{|c|}{65,1048387} & 251,755322 & 248 & & \\
\hline ordinary coverage & OC NN & OC NN (SD) & OC NN NOS & OC NN ANOVA & \\
\hline quantity & $-3,38636364$ & 10,9123696 & 44 & 0,05595721 & 0,003 \\
\hline price & \multicolumn{1}{|l|}{94,8863636} & 338,062613 & 132 & & \\
\hline treatment & T NN & T NN (SD) & T NN NOS & T NN ANOVA & \\
\hline quantity & $-5,28571429$ & 13,5319727 & 21 & 0,0242377 & 0,001 \\
\hline price & 20,5 & 48,7136922 & 22 & & \\
\hline
\end{tabular}

Table 41

Strategic Variable: Proportional Deviation from the Nash Equilibrium

Specifically when sellers compete in price, game theoretic models make a difference between constant and increasing marginal cost (Allen and Hellwig 1986b; Allen and Hellwig 1986a). If this is relevant for the behaviour of experimental subjects, there would have to be an interaction effect between the strategic variable and the distinction between constant and increasing supply. If measured with the $\mathrm{CN}$ or the $\mathrm{NN}$ index, this is not the case ( $\mathrm{p}=0,767$ and 0,104 respectively). If measured with the CW index, there is indeed an interaction effect. But it points into the opposite direction. If marginal cost increases, collusion decreases, instead of increasing, as theory predicts. 


\begin{tabular}{|l|c|c|r|r|}
\hline & constant & constant (SD) & constant NOS & supply Sig. \\
\hline quantity & 55,1666667 & 30,83018 & 90 & 0,00232913 \\
\hline price & 50,7777778 & 31,4432781 & 171 & \\
\hline & decreasing & decreasing (SD) & decreasing NOS & \\
\hline quantity & 35,3823529 & 28,9346334 & 34 & \\
\hline price & 9,61349693 & 29,5284598 & 163 & \\
\hline
\end{tabular}

Table 42

Strategic Variable - Supply Interaction

(normalized deviation from the Walrasian equilibrium)

\section{Simultaneous vs. Sequential Interaction}

If sellers interact sequentially (and if products are homogeneous), theory predicts a smaller deviation from the Walrasian equilibrium if they compete in quantity (Stackelberg 1934). If they compete in price and marginal cost is constant, there should be no deviation from the Walrasian equilibrium. The evidence that does not distinguish between strategic variables does not support these predictions. Sequential interaction increases the deviation from the Walrasian equilibrium, whereas from the theoretical perspective it could at most have been immaterial. The $\mathrm{CN}$ and the NN indices do not yield significant results.

\begin{tabular}{|l|r|r|r|r|r|}
\hline gross & CW & CW (SD) & CW NOS & CW ANOVA & $\begin{array}{l}\text { CW Mann- } \\
\text { Whitney }\end{array}$ \\
\hline simultaneous & 35,0047506 & 36,6532656 & 421 & 0,03624041 & 0,419 \\
\hline sequential & 46,9137931 & 61,7917511 & 58 & & \\
\hline ordinary coverage & OC CW & OC CW (SD) & OC CW NOS & OC CW ANOVA & \\
\hline simultaneous & 18,7161572 & 30,4039002 & 229 & 0,02388349 & 0,097 \\
\hline sequential & 32,8888889 & 32,7100706 & 27 & & \\
\hline treatment & T CW & T CW (SD) & T CW NOS & T CW ANOVA & \\
\hline simultaneous & 66 & 26,8374738 & 9 & 0,72587447 & \\
\hline sequential & 69,125 & 17,3354165 & 16 & & \\
\hline
\end{tabular}

Table 43

Sequence: Normalized Deviation from the Walrasian Equilibrium

\begin{tabular}{|l|l|l|r|r|l|}
\hline treatment & T CN & T CN (SD) & T CN NOS & T CN ANOVA & $\begin{array}{l}\text { T CN Mann } \\
\text { Whitney }\end{array}$ \\
\hline simultaneous & 14,2222222 & 20,8553217 & 9 & 0,15505034 & 0,462 \\
\hline sequential & $-37,0625$ & 102,540703 & 16 & & \\
\hline
\end{tabular}

Table 44

Sequence: Normalized Deviation from the Nash Equilibrium

(data from the gross and the ordinary coverage samples insignificant) 


\begin{tabular}{|l|r|r|r|r|r|}
\hline treatment & T NN & T NN (SD) & T NN NOS & T NN ANOVA & T NN Mann Whitney \\
\hline simultaneous & 3,44444444 & 4,21637021 & 9 & 0,44874205 & 0,691 \\
\hline sequential & 1,125 & 8,39742024 & 16 & & \\
\hline
\end{tabular}

Table 45

Sequence: Proportional Deviation from the Nash Equilibrium

(data from the gross and the ordinary coverage samples insignificant)

If one looks at interaction effects, theory does not fare better. Here, the CN index is significant. But in quantity competition, there is a negative deviation from the Nash equilibrium if interaction is simultaneous. The deviation becomes positive if interaction is sequential. The negative effect of sequential play is even stronger in price competition. Apparently subjects dislike the opportunity for asymmetric gains inherent in sequential interaction.

\begin{tabular}{|l|c|c|r|r|}
\hline & quantity & quantity (SD) & quantity NOS & strategic variable Sig. \\
\hline simultaneous & $-6,37962963$ & 56,0348219 & 108 & 0,04859943 \\
\hline sequential & 11,2105263 & 29,6771123 & 19 & \\
\hline & price & price (SD) & price NOS & \\
\hline simultaneous & 1,78991597 & 87,1664467 & 238 & \\
\hline sequential & $-29,6666667$ & 78,42684 & 27 & \\
\hline
\end{tabular}

Table 46

Sequence - Strategic Variable Interaction

(normalised deviation from the Nash equilibrium)

\section{Duration of the Interaction between Sellers}

Strictly speaking, theory does not predict that longer duration means more collusion. If subjects are informed about the exact duration, via backwards induction, the prisoner's dilemma from the one-shot game is re-established (Selten 1978). If the end is uncertain, according to the folk theorem, there are multiple equilibria (Aumann and Shapley 1994). However, if one allows for a small deviation from strict rationality, and if the discount factor is not too large, a longer shadow of the future makes collusion more attractive (see e.g. Fudenberg and Tirole 1991:146-150). This expectation is at best weakly supported by the experimental evidence. If one restricts the sample to experiments with ordinary coverage, a linear regression yields a significant result for the CW and the NN indices. It indeed supports the view that longer duration increases collusion. One should, however, be aware of a qualification. Time series evidence demonstrates that collusion may go down again if the game is repeated very many times (Alger 1987). 


\begin{tabular}{|l|c|c|c|l|}
\hline gross & CW B & CW B SD & CW Beta & CW Sig. \\
\hline & 0,20048684 & 0,11456625 & 0,08988223 & 0,0809402 \\
\hline & CW Const & CW Const SD & CW Const Sig \\
\hline & 38,3053538 & 3,5195464 & & \\
\hline & CW R^2 & CW adj. $R^{\wedge} 2$ & & \\
\hline & 0,00807882 & 0,00544073 & & \\
\hline ordinary coverage & OC CW B & OC CW B SD & OC CW Beta & OC CW Sig. \\
\hline & 0,45946574 & 0,13504525 & 0,24908425 & 0,00082811 \\
\hline & OC CW Const & OC CW Const SD & OC CW Const Sig \\
\hline & 16,2235714 & 3,46183856 & & \\
\hline & OC CW R^2 & OC CW adj.R^2 & \\
\hline & 0,06204296 & 0,05668321 & & \\
\hline & $T$ CW B & T CW B SD & T CW Beta & T CW Sig. \\
\hline & $-0,29934652$ & 0,30796074 & $-0,14832808$ & \\
\hline & $T$ CW Const & T CW Const SD & T CW Const Sig \\
\hline & 63,8339001 & 7,47471927 & & \\
\hline & $T$ CW R^2 & T CW adj.R^2 & \\
\hline & 0,02200122 & $-0,00128447$ & & \\
\hline
\end{tabular}

Table 47

Duration: Normalized Deviation from the Walrasian Equilibrium: Regression

\begin{tabular}{|r|c|c|c|r|}
\hline treatment & T CN B & T CN B SD & T CN Beta & T CN Sig. \\
\hline & 1,23323459 & 0,90890613 & 0,20492099 & 0,18208216 \\
\hline & T CN Const & T CN Const SD & & T CN Const Sig \\
\hline & $-40,9577591$ & 22,0606634 & & 0,07039197 \\
\hline & T CN R^2 & T CN adj.R 2 & & \\
\hline & 0,04199261 & 0,01918291 & & \\
\hline
\end{tabular}

Table 48

Duration: Normalized Deviation from the Nash Equilibrium: Regression (estimates from gross and ordinary coverage samples insignificant)

\begin{tabular}{|l|c|c|c|c|}
\hline gross & NN B & NN B SD & NN Beta & NN Sig. \\
\hline & 0,994591 & 0,58728859 & 0,08700595 & 0,09118278 \\
\hline & NN Const & NN Const SD & & NN Const Sig \\
\hline & 18,0101709 & 18,0418708 & & 0,31880353 \\
\hline & NN R^2 & NN adj. $R^{\wedge} 2$ & & \\
\hline & 0,00757004 & 0,0049306 & & \\
\hline ordinary coverage & OC NN B & OC NN B SD & OC NN Beta & OC NN Sig. \\
\hline & 4,47582732 & 1,36914249 & 0,23990213 & 0,00129911 \\
\hline & OC NN Const & OC NN Const SD & OC NN Const Sig \\
\hline & $-20,4405987$ & 35,0974968 & & 0,5610504 \\
\hline & OC NN R^2 & OC NN adj.R^2 & \\
\hline & 0,05755303 & 0,05216762 & & T \\
\hline & $T$ NN B & T NN B SD & T NN Beta & T NN Sig. \\
\hline & 0,7784434 & 0,39897747 & 0,28827953 & 0,05773736 \\
\hline & $T$ NN Const & T NN Const SD & T NN Const Sig \\
\hline & $-9,81206372$ & 9,6838468 & & 0,3167472 \\
\hline & $T$ NN R^2 & T NN adj.R^2 & & \\
\hline & 0,08310509 & 0,06127426 & & \\
\hline
\end{tabular}

Table 49

Duration: Proportional Deviation from the Nash Equilibrium: Regression 


\section{Partner vs. Stranger Design}

It is more interesting, and more relevant, to compare experiments that had a fixed partner design with others that rematched subjects from round to round. On average, the latter manipulation increases collusion with respect to all three indices.

\begin{tabular}{|l|l|l|r|r|r|}
\hline gross & CW & CW (SD) & CW NOS & CW ANOVA & $\begin{array}{l}\text { CW Mann- } \\
\text { Whitney }\end{array}$ \\
\hline partner & 34,5250597 & 42,0143085 & 419 & 0,006 & 0,001 \\
\hline stranger & 49,8666667 & 25,682195 & 60 & & \\
\hline ordinary coverage & OC CW & OC CW (SD) & OC CW NOS & OC CW ANOVA & \\
\hline partner & 16,7882883 & 30,6395664 & 222 & 0 & \\
\hline stranger & 42,5588235 & 22,2794799 & 34 & & \\
\hline treatment & T CW & T CW (SD) & T CW NOS & T CW ANOVA & \\
\hline partner & 61,8421053 & 21,5748391 & 19 & 0,853 & 0,811 \\
\hline stranger & 60,5 & 23,2797631 & 20 & & \\
\hline
\end{tabular}

Table 50

Partner vs. Stranger Design

Normalized Deviation from the Walrasian Equilibrium

\begin{tabular}{|l|l|l|r|r|r|}
\hline ordinary coverage & OC CN & OC CN (SD) & OC CN NOS & OC CN ANOVA & \multicolumn{2}{l|}{$\begin{array}{l}\text { nN Mann Whit- } \\
\text { ney }\end{array}$} \\
\hline partner & $-11,8846154$ & 87,1616194 & 156 & 0,086 & 0 \\
\hline stranger & 15,3870968 & 22,8599758 & 31 & & \\
\hline treatment & T CN & T CN (SD) & T CN NOS & T CN ANOVA & \\
\hline partner & $-8,89473684$ & 70,2178315 & 19 & 0,656 & 0,440 \\
\hline stranger & $-20,05$ & 84,0829634 & 20 & & \\
\hline
\end{tabular}

Table 51

Partner vs. Stranger Design

Normalized Deviation from the Nash Equilibrium

(gross data insignificant)

\begin{tabular}{|l|r|r|r|r|r|}
\hline gross & NN & NN (SD) & NN NOS & NN ANOVA & $\begin{array}{l}\text { NN Mann- } \\
\text { Whitney }\end{array}$ \\
\hline partner & 24,0684524 & 151,842804 & 336 & 0 & \\
\hline stranger & 158,313725 & 389,258448 & 51 & & \\
\hline ordinary coverage & OC NN & OC NN (SD) & OC NN NOS & OC NN ANOVA & \\
\hline partner & 30,5666667 & 219,584581 & 150 & 0 & 0 \\
\hline stranger & 268,275862 & 491,13243 & 29 & & \\
\hline treatment & T NN & T NN (SD) & T NN NOS & T NN ANOVA & \\
\hline partner & 13,2631579 & 42,6872894 & 19 & 0,523 & 0,704 \\
\hline stranger & 6,35 & 21,4089873 & 20 & & \\
\hline
\end{tabular}

Table 52

Partner vs. Stranger Design

Proportional Deviation from the Nash Equilibrium

These are surprising findings, both compared to the theoretical prediction, and to the findings in those experiments that had the distinction between partner and stranger design as a treatment variable. From the already mentioned folk theorem it follows that theory makes no clear predic- 
tion for the repeated game (Aumann and Shapley 1994). But one result is beyond doubt. In oneshot interaction, there is no collusive equilibrium. (Bertrand 1883) and (Cournot 1838) agree on this. It is equally remarkable that in the subsample with experiments that explicitly tested for the effect, the distinction between the partner and the stranger design is insignificant for all three indices.

For understanding these findings, it is helpful to look at interaction effects. In duopoly markets, shifting from partner to stranger design slightly reduces collusion. The larger the market, however, the stronger the positive effect of a stranger design on the degree of collusion. Moreover, the effect of stranger interaction on collusion is sensitive to information. With poor ex ante information or feedback, strangers collude more than partners. With full ex ante or feedback information, the effect reverses.

\begin{tabular}{|c|c|c|c|c|}
\hline size & size 2 & size $2(\mathrm{SD})$ & size 2 NOS & size Sig. \\
\hline partner & 64,21875 & 42,6758405 & 128 & 0,00531679 \\
\hline \multirow[t]{2}{*}{ stranger } & 55,2857143 & 23,3535127 & 35 & \\
\hline & size 3 & size $3(\mathrm{SD})$ & size 3 NOS & \\
\hline partner & 42,4782609 & 34,2192794 & 69 & \\
\hline \multirow[t]{2}{*}{ stranger } & 44,2 & 40,6114379 & 10 & \\
\hline & size 4 & size $4(\mathrm{SD})$ & size 4 NOS & \\
\hline partner & 12,9111111 & 33,4133914 & 135 & \\
\hline stranger & 47 & 16,4519502 & 7 & \\
\hline $\begin{array}{l}\text { ex ante informa- } \\
\text { tion }\end{array}$ & reduced ex ante & reduced ex ante (SD) & reduced ex ante NOS & ex ante Sig. \\
\hline partner & 18,1166667 & 39,8512325 & 120 & 0,04375676 \\
\hline \multirow[t]{2}{*}{ stranger } & 57,1666667 & 9,66264284 & 6 & \\
\hline & partial ex ante & partial ex ante (SD) & partial ex ante NOS & \\
\hline partner & 37,9047619 & 32,7132923 & 84 & \\
\hline \multirow[t]{2}{*}{ stranger } & 42,8333333 & 13,9773627 & 6 & \\
\hline & full ex ante & full ex ante (SD) & full ex ante NOS & \\
\hline partner & 53,8106061 & 46,1180253 & 132 & \\
\hline stranger & 49,8333333 & 28,0025328 & 48 & \\
\hline feedback & $\begin{array}{l}\text { reduced feed- } \\
\text { back }\end{array}$ & $\begin{array}{l}\text { reduced feedback } \\
\text { (SD) }\end{array}$ & $\begin{array}{l}\text { reduced feedback } \\
\text { NOS }\end{array}$ & $\begin{array}{l}\text { feedback } \\
\text { Sig. }\end{array}$ \\
\hline partner & 2,53521127 & 28,2402099 & 71 & 0,00692665 \\
\hline \multirow{2}{*}{ stranger } & 48,6666667 & 21,825062 & 3 & \\
\hline & partial feedback & partial feedback (SD) & partial feedback NOS & \\
\hline partner & 36,0593607 & 36,9249318 & 219 & \\
\hline \multirow[t]{2}{*}{ stranger } & 52,3793103 & 23,7793635 & 29 & \\
\hline & full feedback & full feedback (SD) & full feedback NOS & \\
\hline partner & 59,12 & 52,0599862 & 75 & \\
\hline stranger & 47,3928571 & 28,3957995 & 28 & \\
\hline
\end{tabular}

Table 53

Partner vs. Stranger Design: Interaction Effects

(normalized deviation from the Walrasian equilibrium) 
This explanation is corroborated if one checks the distribution of market sizes in the subsample that has explicitly tested the stranger versus the partner design. 33 experiments had a duopoly market, 6 a quadropoly. 27 had full, 12 partial ex ante information, none reduced information. 18 had full and 18 partial, and only 3 reduced feedback. In the subsample, treatment variables are thus overrepresented that dampen the effect of a stranger design on collusion.

\section{Effect of Communication on Collusion}

In game theoretic terms, competition puts sellers into a prisoner's dilemma. ${ }^{11}$ If they have a chance to talk before play, from a theoretical perspective this is just irrelevant "cheap talk" (for background and alternative models see Crawford 1998). Indeed, the main effect is not significant with respect to the $\mathrm{CW}$ and the $\mathrm{NN}$ indices. Only the $\mathrm{CN}$ index shows what common sense would expect: communication increases collusion.

\begin{tabular}{|l|r|r|r|r|r|}
\hline treatment & T CW & T CW (SD) & T CW NOS & T CW ANOVA & \multicolumn{2}{l|}{ T CW Mann } \\
Whitney
\end{tabular}

Table 54

Communication: Normalized Deviation from the Walrasian Equilibrium (data from gross and ordinary coverage samples insignificant)

\begin{tabular}{|l|r|r|r|r|r|}
\hline gross & \multicolumn{1}{|l|}{} & CN & CN NOS & CN ANOVA & $\begin{array}{l}\text { CN Mann- } \\
\text { Whitney }\end{array}$ \\
\hline no communication & $-4,99171271$ & 80,3984705 & 362 & 0,0349576 & 0,006 \\
\hline communication & 21,5714286 & 35,1374603 & 42 & & \\
\hline treatment & T CN & T CN (SD) & T CN NOS & T CN ANOVA & \\
\hline no communication & 3,11111111 & 21,1509128 & 9 & 0,003486 & 0,003 \\
\hline communication & 45 & 33,4713808 & 13 & & \\
\hline
\end{tabular}

Table 55

Communication: Normalized Deviation from the Nash Equilibrium (data from ordinary coverage sample insignificant)

\begin{tabular}{|l|r|l|r|r|r|}
\hline treatment & \multicolumn{1}{|l|}{} & & & \multicolumn{2}{l|}{ T NN Mann } \\
T NN & T NN (SD) & T NN NOS & T NN ANOVA & Whitney \\
\hline no communication & 29,875 & 65,9641407 & 8 & 0,19233194 & 0,051 \\
\hline communication & 116,9 & 170,040159 & 10 & & \\
\hline
\end{tabular}

Table 56

Communication: Proportional Deviation from the Nash Equilibrium

(data from gross and ordinary coverage samples insignificant)

11 Strictly speaking, this only holds if marginal cost increases. But if the supply curve differs from this, the parties still face a dilemma. 
However, if one looks at interaction effects, the picture changes dramatically. Many of them are significant, and they matter in practical terms. In a duopoly, collusion, expressed as the deviation from the Walrasian equilibrium, is even slightly reduced. In triopoly, however, collusion jumps up. If sellers compete in price, communication reduces collusion. If they compete in quantity, communication strongly increases collusion. Inexperienced subjects slightly suffer from communication. Experienced subjects may dramatically increase collusion if they are allowed to talk. In simultaneous interaction, communication strongly increases collusion. In sequential interaction, the opposite is true. Finally with poor ex ante information, communication strongly reduces collusion, whereas with more ex ante information the opposite holds true, in particular with partial ex ante information. With poor and with full feedback, communication increases collusion. With partial feedback, collusion is reduced.

\begin{tabular}{|c|c|c|c|c|}
\hline market size & size 2 & size 2 (SD) & size 2 NOS & $\begin{array}{l}\text { market size } \\
\text { Sig }\end{array}$ \\
\hline no communication & 52,7755102 & 18,2314578 & 49 & 0,0291289 \\
\hline \multirow[t]{2}{*}{ communication } & 22,75 & 28,1469359 & 4 & \\
\hline & size 3 & size $3(\mathrm{SD})$ & size 3 NOS & \\
\hline no communication & 19,173913 & 29,7071344 & 23 & \\
\hline \multirow[t]{2}{*}{ communication } & 52 & 14,1421356 & 2 & \\
\hline & size 4 & size $4(\mathrm{SD})$ & size 4 NOS & \\
\hline no communication & 10,9032258 & 32,1024395 & 93 & \\
\hline communication & 7,46153846 & 19,504766 & 13 & \\
\hline strategic variable & quantity & quantity (SD) & quantity NOS & $\begin{array}{l}\text { strategic vari- } \\
\text { able Sig. }\end{array}$ \\
\hline no communication & 46,6052632 & 31,3782571 & 114 & 0,0009569 \\
\hline \multirow[t]{2}{*}{ communication } & 74,1538462 & 14,3052796 & 13 & \\
\hline & price & price (SD & price NOS & \\
\hline no communication & 74,1538462 & 14,3052796 & 13 & \\
\hline communication & 17,24 & 27,2752635 & 25 & \\
\hline experience & no experience & no experience (SD) & no experience NOS & $\begin{array}{l}\text { experience } \\
\text { Sig. }\end{array}$ \\
\hline no communication & 38,3288043 & 40,3590566 & 368 & 0,00539321 \\
\hline \multirow[t]{2}{*}{ communication } & 35,9166667 & 50,597219 & 36 & \\
\hline & experience & experience (SD) & experience NOS & \\
\hline no communication & 23,5217391 & 34,4005851 & 69 & \\
\hline communication & 72,8333333 & 9,74508423 & 6 & \\
\hline sequence & simultaneous & simultaneous (SD) & simulataneous $\mathrm{N}$ & sequence Sig. \\
\hline no communication & 33,9287532 & 36,738458 & 393 & 0,00130297 \\
\hline \multirow[t]{2}{*}{ communication } & 50,1071429 & 32,3892292 & 28 & \\
\hline & sequential & sequential (SD) & sequential NOS & \\
\hline no communication & 54,4090909 & 58,1326943 & 44 & \\
\hline communication & 23,3571429 & 69,1059467 & 14 & \\
\hline ex ante information & $\begin{array}{l}\text { ex ante re- } \\
\text { duced }\end{array}$ & $\begin{array}{l}\text { ex ante reduced } \\
\text { (SD) }\end{array}$ & $\begin{array}{l}\text { ex ante reduced } \\
\text { NOS }\end{array}$ & *ex ante Sig. \\
\hline no communication & 21,3333333 & 41,1579446 & 114 & 0,03125792 \\
\hline \multirow[t]{2}{*}{ communication } & 7,08333333 & 20,322215 & 12 & \\
\hline & ex ante partial & ex ante partial (SD) & ex ante partial NOS & \\
\hline no communication & 33,9480519 & 31,2426396 & 77 & \\
\hline communication & 63,6153846 & 22,2917715 & 13 & \\
\hline
\end{tabular}




\begin{tabular}{|c|c|c|c|c|}
\hline & ex ante full & ex ante full (SD) & ex ante full NOS & \\
\hline no communication & 52,1197605 & 39,6774347 & 167 & \\
\hline communication & 60,8461538 & 66,9450598 & 13 & \\
\hline $\begin{array}{l}\text { feedback informa- } \\
\text { tion }\end{array}$ & $\begin{array}{l}\text { reduced feed- } \\
\text { back }\end{array}$ & $\begin{array}{l}\text { reduced feedback } \\
\text { (SD) }\end{array}$ & $\begin{array}{l}\text { reduced feedback } \\
\text { NOS }\end{array}$ & *feedback Sig. \\
\hline no communication & 4,15942029 & 29,7744577 & $\begin{array}{r}69 \\
\end{array}$ & 0,0173197 \\
\hline \multirow[t]{2}{*}{ communication } & 7,8 & 25,2922913 & 5 & \\
\hline & partial feedback & partial feedback (SD) & partial feedback NOS & \\
\hline no communication & 39,650655 & 36,1609494 & 229 & \\
\hline \multirow[t]{2}{*}{ communication } & 17,6842105 & 27,166263 & 19 & \\
\hline & full feedback & full feedback (SD) & full feedback NOS & \\
\hline no communication & 53,9354839 & \begin{tabular}{|r|}
43,9032549 \\
\end{tabular} & 93 & \\
\hline communication & 74,5 & 69,9082732 & 10 & \\
\hline
\end{tabular}

Table 57

Communication: Interaction Effects

(normalized deviation from the Walrasian equilibrium)

\section{Option to Agree}

While mere communication should be irrelevant, at least in standard settings, from a theoretical perspective the possibility to conclude an enforceable agreement should make all the difference. Against this backdrop, the experimental evidence is somewhat disappointing. Some of the indices are insignificant in some compositions of the sample. The significant results in the gross sample, especially with respect to the $\mathrm{CW}$ index, are far from impressive.

\begin{tabular}{|l|l|l|r|r|r|}
\hline gross & CW & CW (SD) & CW NOS & CW ANOVA & $\begin{array}{l}\text { CW Mann- } \\
\text { Whitney }\end{array}$ \\
\hline no agreement & 35,6111111 & 39,5691423 & 450 & 0,07618281 & 0,277 \\
\hline agreement & 49,4137931 & 53,7603925 & 29 & & \\
\hline treatment & T CW & T CW (SD) & T CW NOS & T CW ANOVA & \\
\hline no agreement & 43,4444444 & 126,973532 & 9 & 0,59879067 & 0,021 \\
\hline agreement & 71,25 & 76,5501703 & 8 & & \\
\hline
\end{tabular}

Table 58

Agreement: Normalized Deviation from the Walrasian Equilibrium (data from the ordinary coverage sample insignificant)

\begin{tabular}{|l|r|l|r|r|r|}
\hline gross & CN & CN (SD) & CN NOS & CN ANOVA & $\begin{array}{l}\text { CN Mann- } \\
\text { Whitney }\end{array}$ \\
\hline no agreement & $-4,44$ & 79,5724605 & 375 & 0,03875631 & 0,001 \\
\hline agreement & 26,3448276 & 24,6783246 & 29 & & \\
\hline treatment & T CN & T CN (SD) & T CN NOS & T CN ANOVA & \\
\hline no agreement & 11,6666667 & 47,2678538 & 9 & 0,10095232 & 0,016 \\
\hline agreement & 43,25 & 20,2607996 & 8 & & \\
\hline
\end{tabular}

Table 59

Agreement: Normalized Deviation from the Nash Equilibrium

(data from the ordinary coverage sample insignificant) 


\begin{tabular}{|l|r|r|r|r|rr|}
\hline treatment & \multicolumn{1}{|l|}{ T NN } & \multicolumn{1}{|l|}{ T NN (SD) } & \multicolumn{2}{|l|}{ T NN NOS } & T NN ANOVA & $\begin{array}{l}\text { T NN Mann } \\
\text { Whitney }\end{array}$ \\
\hline no agreement & 43,625 & 79,2679678 & 8 & 0,13445532 & 0,079 \\
\hline agreement & 182 & 225,985619 & 5 & & & \\
\hline
\end{tabular}

Table 60

Agreement: Proportional Deviation from the Nash Equilibrium

(data from the gross and ordinary coverage samples insignificant)

As with communication, the many significant interaction effects are of greater interest. In duopoly, agreement matters most. In triopoly it still increases collusion remarkably. In quadropoly, however, the chance to agree even reduces collusion, as measured with the CW index. If buyers are simulated by a price taking computer, the effect of an opportunity to agree on collusion is much stronger than with human buyers. The chance to agree strongly increases collusion if sellers compete in quantity; it reduces collusion if they compete in price. Experienced subjects make much better use of the opportunity to conclude an agreement. If interaction is simultaneous, the opportunity to agree helps. If interaction is sequential, it hurts. If sellers are symmetric, agreement has a strong positive effect on collusion. Asymmetry dampens the effect strongly. If capacity is unconstrained, the effect of a chance to agree on collusion is much stronger than with constrained capacity. Finally, the effect of an agreement opportunity is sensitive to the information environment. If ex ante information is reduced, collusion even decreases. If ex ante information is partial, the effect is mildly positive. It is strongly positive with full ex ante information. Full feedback has a similar effect. However, in feedback, the chance to agree has a negative effect in the partial, not in the reduced specification.

\begin{tabular}{|c|c|c|c|c|}
\hline market size & size 2 & size 2 (SD) & size 2 NOS & size Sig \\
\hline no agreement & 60,7484277 & 36,766793 & 159 & 0,00052927 \\
\hline \multirow[t]{2}{*}{ agreement } & 124 & 87,2505969 & 4 & \\
\hline & size 3 & size $3(\mathrm{SD})$ & size 3 NOS & \\
\hline no agreement & 37,8059701 & 34,9550529 & 67 & \\
\hline \multirow[t]{2}{*}{ agreement } & 70 & $\begin{array}{r}17,3310022 \\
\end{array}$ & 12 & \\
\hline & size 4 & size $4(\mathrm{SD})$ & size 4 NOS & \\
\hline no agreement & 15,3100775 & 34,6488633 & 129 & \\
\hline agreement & 7,46153846 & 19,504766 & 13 & \\
\hline $\begin{array}{l}\text { computer/human } \\
\text { buyer }\end{array}$ & computer & computer (SD) & computer NOS & $\begin{array}{l}\text { computer/human buy- } \\
\text { er Sig. }\end{array}$ \\
\hline no agreement & 41,3007916 & 38,7223091 & 379 & 0,0079757 \\
\hline \multirow[t]{2}{*}{ agreement } & 88,3571429 & 49,0174335 & 14 & \\
\hline & human & human (SD) & human NOS & \\
\hline no agreement & 5,23943662 & 28,9000567 & 71 & \\
\hline agreement & 13,0666667 & 24,8437019 & 15 & \\
\hline strategic variable & quantity & quantity (SD) & quantity NOS & stratvar Sig. \\
\hline no agreement & 46,6034483 & 31,1199305 & 116 & 0,00066389 \\
\hline \multirow[t]{2}{*}{ agreement } & 79,1818182 & 7,31871822 & 11 & \\
\hline & price & price (SD & price NOS & \\
\hline no agreement & 31,1180124 & 37,0472257 & 322 & \\
\hline agreement & 15,0625 & 25,2941858 & 16 & \\
\hline
\end{tabular}




\begin{tabular}{|c|c|c|c|c|}
\hline experience & no experience & \begin{tabular}{|l|} 
no experience \\
(SD)
\end{tabular} & $\begin{array}{l}\text { no experience } \\
\text { NOS }\end{array}$ & experience Sig. \\
\hline no agreement & 37,6754617 & 40,1549605 & 379 & 0,03623788 \\
\hline \multirow[t]{2}{*}{ agreement } & 44,76 & 56,6092454 & 25 & \\
\hline & experience & experience (SD) & experience NOS & \\
\hline no agreement & 24,5915493 & 34,4912318 & 71 & \\
\hline agreement & 78,5 & 5,44671155 & 4 & \\
\hline sequence & simultaneous & simultaneous (SD) & simultaneous NOS & sequence Sig. \\
\hline no agreement & 33,7054455 & 36,5721676 & 404 & 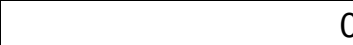 \\
\hline \multirow[t]{2}{*}{ agreement } & 65,8823529 & 22,8333154 & 17 & \\
\hline & sequential & sequential (SD) & sequential NOS & \\
\hline no agreement & 52,3478261 & 57,6642456 & 46 & \\
\hline agreement & 26,0833333 & 74,7364562 & 12 & \\
\hline symmetry & symmetric & symmetric (SD) & symmetric NOS & symmetry Sig. \\
\hline no agreement & 38,0614887 & 40,1913375 & 309 & 0,01223149 \\
\hline \multirow[t]{2}{*}{ agreement } & 93,1666667 & 80,0834981 & 6 & \\
\hline & asymmetric & asymmetric (SD) & asymmetric NOS & \\
\hline no agreement & 30,2411348 & 37,7548295 & 141 & \\
\hline agreement & 38 & 39,5290457 & 23 & \\
\hline capacity & unconstrained & $\begin{array}{l}\text { unconstrained } \\
\text { (SD) }\end{array}$ & \begin{tabular}{|l|} 
unconstrained \\
NOS
\end{tabular} & capacity Sig. \\
\hline no agreement & 52,8299595 & 37,0413337 & 247 & 0,01611412 \\
\hline \multirow[t]{2}{*}{ agreement } & 116,4 & 77,4486927 & 5 & \\
\hline & constrained & constrained (SD) & constrained NOS & \\
\hline no agreement & 14,6600985 & 31,7120044 & 203 & \\
\hline agreement & 35,4583333 & 36,008428 & 24 & \\
\hline $\begin{array}{l}\text { ex ante informa- } \\
\text { tion }\end{array}$ & $\begin{array}{l}\text { ex ante re- } \\
\text { duced }\end{array}$ & $\begin{array}{l}\text { ex ante reduced } \\
\text { (SD) }\end{array}$ & \begin{tabular}{|l|} 
ex ante reduced \\
NOS
\end{tabular} & ex ante Sig. \\
\hline no agreement & 21,3333333 & 41,1579446 & 114 & 0 \\
\hline \multirow[t]{2}{*}{ agreement } & 7,08333333 & 20,322215 & 12 & \\
\hline & ex ante partial & \begin{tabular}{l|} 
ex ante partial \\
(SD)
\end{tabular} & ex ante partial NOS & \\
\hline no agreement & 34,2948718 & 31,1898706 & 78 & \\
\hline \multirow[t]{2}{*}{ agreement } & 63,8333333 & 23,2685247 & 12 & \\
\hline & ex ante full & ex ante full (SD) & ex ante full NOS & \\
\hline no agreement & 50,9314286 & 39,4796017 & 175 & \\
\hline agreement & 116,4 & \begin{tabular}{|l}
77,4486927 \\
\end{tabular} & 5 & \\
\hline $\begin{array}{l}\text { feedback informa- } \\
\text { tion }\end{array}$ & \begin{tabular}{l|} 
reduced \\
feedback
\end{tabular} & $\begin{array}{l}\text { reduced feedback } \\
\text { (SD) }\end{array}$ & $\begin{array}{l}\text { reduced feedback } \\
\text { NOS }\end{array}$ & feedback Sig. \\
\hline no agreement & 6,44871795 & 30,7755374 & 78 & 0 \\
\hline \multirow[t]{2}{*}{ agreement } & 12 & & 1 & \\
\hline & $\begin{array}{l}\text { partial feed- } \\
\text { back }\end{array}$ & $\begin{array}{l}\text { partial feedback } \\
\text { (SD) }\end{array}$ & partial feedback NOS & \\
\hline no agreement & 38,942623 & 35,5777244 & 244 & \\
\hline \multirow[t]{2}{*}{ agreement } & 13,1428571 & 25,7797092 & 14 & \\
\hline & full feedback & full feedback (SD) & full feedback NOS & \\
\hline no agreement & 52,9278351 & 43,524717 & 97 & \\
\hline agreement & 88,3571429 & 49,0174335 & 14 & \\
\hline
\end{tabular}

Table 61

Agreement: Interaction Effects

(normalized deviation from the Walrasian equilibrium) 


\section{Dependence of Collusion on the Information Environment}

\section{Role of Ex Ante Information}

From the very first oligopoly experiments on, experimenters have manipulated the information they have given their subjects, both in advance and as feedback to their choices in previous rounds (e.g. Fouraker and Siegel 1963). The effect of ex ante information on deviations from the Walrasian equilibrium is straightforward. The better subjects are informed, the more they collude. The effect on deviations from the Nash equilibrium is less clear. The only significant finding is in the sample reduced to experiments with ordinary coverage, and with respect to the NN index. Collusion increases from reduced to full ex ante information, but it is lowest with partial ex ante information.

The distinction between full and partial ex ante information is net. If subjects are fully informed, they are able to calculate their competitors' profits. With partial information, they are only able to anticipate their own profit. The reduced information category is less strictly defined. It encompasses all situations where subjects receive yet less information. Often this means that they have no full knowledge of demand. Sometimes, there is cost uncertainty. ${ }^{12}$

\begin{tabular}{|l|r|l|r|r|r|}
\hline & CW & CW (SD) & CW NOS & CW ANOVA & $\begin{array}{l}\text { CW Kruskal- } \\
\text { Wallis }\end{array}$ \\
\hline gross & 19,9761905 & 39,8162709 & 126 & 0 & 0 \\
\hline partial ex ante information & 38,2333333 & 31,7886454 & 90 & & \\
\hline full ex ante information & 52,75 & 42,0183353 & 180 & & \\
\hline & & OC CW & OC CW & OC CW ANO- & \\
ordinary coverage & OC CW & (SD) & NOS & VA & \\
\hline reduced ex ante information & 7,90588235 & 28,3026263 & 85 & & \\
\hline partial ex ante information & 22,6428571 & 28,8273426 & 42 & & \\
\hline full ex ante information & 36,8064516 & 30,2328877 & 62 & & \\
\hline treatment & T CW & T CW (SD) & T CW NOS & T CW ANOVA & \\
\hline reduced ex ante information & $-4,4$ & 32,9787811 & 10 & 0,00313307 & 0,002 \\
\hline partial ex ante information & 31,5 & 27,6973439 & 8 & & \\
\hline full ex ante information & 42,2307692 & 28,8968102 & 13 & & \\
\hline
\end{tabular}

Table 62

Ex ante Information: Normalized Deviation from the Walrasian Equilibrium

\begin{tabular}{|c|c|c|c|c|c|}
\hline treatment & $\mathrm{T} C \mathrm{CN}$ & T CN (SD) & T CN NOS & $\begin{array}{l}\text { T CN ANO- } \\
\text { VA }\end{array}$ & $\begin{array}{l}\text { T CN Kruskal } \\
\text { Wallis }\end{array}$ \\
\hline reduced ex ante information & $-26,2$ & 75,3713768 & 10 & 0,64802787 & 0,628 \\
\hline partial ex ante information & $-17,875$ & 24,82762 & 8 & & \\
\hline full ex ante information & $-5,38461539$ & 45,2797572 & 13 & & \\
\hline
\end{tabular}

Table 63

Ex ante Information: Normalized Deviation from the Nash Equilibrium

(data from the gross and ordinary coverage samples insignificant) 


\begin{tabular}{|l|r|r|r|r|r|}
\hline ordinary coverage & OC NN & OC NN (SD) & OC NN NOS & $\begin{array}{l}\text { OC NN ANO- } \\
\text { VA }\end{array}$ & $\begin{array}{l}\text { NN Kruskal } \\
\text { Wallis }\end{array}$ \\
\hline $\begin{array}{l}\text { reduced ex ante infor- } \\
\text { mation }\end{array}$ & 36,2051282 & 104,676238 & 39 & 0,05581643 & 0,143 \\
\hline $\begin{array}{l}\text { partial ex ante informa- } \\
\text { tion }\end{array}$ & 5,80952381 & 32,7304126 & 42 & & \\
\hline full ex ante information & 124,727273 & 384,742986 & 55 & & \\
\hline treatment & T NN & T NN (SD) & T NN NOS & T NN ANOVA & \\
\hline $\begin{array}{l}\text { reduced ex ante infor- } \\
\text { mation }\end{array}$ & 11,3 & 49,073754 & 10 & 0,69951372 & 0,585 \\
\hline $\begin{array}{l}\text { partial ex ante informa- } \\
\text { tion }\end{array}$ & $-0,25$ & 18,3595051 & 8 & & \\
\hline full ex ante information & 19,0769231 & 62,9542976 & 13 & & \\
\hline
\end{tabular}

Table 64

Ex ante Information: Proportional Deviation from the Nash Equilibrium

(data from the gross sample insignificant)

The picture becomes much clearer if one looks at interaction effects. For markets of different size, ex ante information matters differently. In duopoly, collusion is highest with reduced information. It is lowest with partial information. Collusion with full information is slightly above collusion with partial information. The shape of the interaction curve is reversed with triopoly and quadropoly. Here collusion is lowest with reduced ex ante information, and highest with partial information. There is also a net difference between competition in quantity and in price. With reduced ex ante information, collusion is much higher if subjects compete in price. This reverses with partial and full information. Now the deviation from the Walrasian equilibrium is higher with competition in quantity.

Communication yields a similar pattern. If subjects are allowed to communicate, but severely lack information, they collude less than if they are better informed. With partial or full information, however, communication strongly increases collusion. If they are allowed to conclude an agreement, the pattern is in principle the same. However, partial information has a less pronounced impact on collusion if agreements are permitted. The situation is comparable with fixed cost. If ex ante information is reduced, fixed cost leads to less collusion than without fixed cost. With partial or full information, however, there is more collusion in fixed cost treatments. With asymmetry, the only noticeable difference is in full ex ante information environments. With this much information, subjects collude much more, whereas the level of collusion is about the same with reduced and partial information. If capacity is unconstrained, reduced ex ante information leads to very high collusion. Collusion is lowest with partial information, and somewhere in the middle with full information. Collusion with constrained capacity is almost the exact opposite. Finally, with homogeneous products, ex ante information has the standard effect. The effect reverses, however, if products are substitutes. 


\begin{tabular}{|c|c|c|c|c|}
\hline size & size 2 & size $2(\mathrm{SD})$ & size 2 NOS & size Sig. \\
\hline reduced & 78,2 & 27,3406494 & 10 & 0,05778036 \\
\hline partial & 60 & 23,1372715 & 19 & \\
\hline \multirow[t]{2}{*}{ full } & 63,661157 & 42,0875187 & 121 & \\
\hline & size 3 & size $3(\mathrm{SD})$ & size 3 NOS & \\
\hline reduced & 41 & 49,6329384 & 15 & \\
\hline partial & 49,5517241 & 26,6439302 & 29 & \\
\hline \multirow[t]{2}{*}{ full } & 37,3333333 & 33,3439064 & 30 & \\
\hline & size 4 & size $4(\mathrm{SD})$ & size 4 NOS & \\
\hline reduced & 9,61643836 & 32,544683 & 73 & \\
\hline partial & 30,6 & 33,3441386 & 20 & \\
\hline full & 18,6 & 36,2014207 & 15 & \\
\hline $\begin{array}{l}\text { strategic vari- } \\
\text { able }\end{array}$ & quantity & quantity (SD) & quantity NOS & $\begin{array}{l}\text { strategic variable } \\
\text { Sig. }\end{array}$ \\
\hline reduced & $-16,3333333$ & 41,4568048 & 6 & 0 \\
\hline partial & 52,2105263 & 26,7340838 & 38 & \\
\hline \multirow[t]{2}{*}{ full } & 55,4358974 & 25,6927853 & 78 & \\
\hline & price & price $(S D)$ & price NOS & \\
\hline reduced & 21,907563 & 39,1732336 & 119 & \\
\hline partial & 28,0192308 & 31,5118965 & 52 & \\
\hline full & 46,7826087 & 32,9591242 & 92 & \\
\hline communication & \begin{tabular}{|l|} 
no communica- \\
tion
\end{tabular} & $\begin{array}{l}\text { no communication } \\
\text { (SD) }\end{array}$ & $\begin{array}{l}\text { no communication } \\
\text { NOS }\end{array}$ & $\begin{array}{l}\text { communication } \\
\text { Sig. }\end{array}$ \\
\hline reduced & 21,3333333 & 41,1579446 & 114 & 0,03125792 \\
\hline partial & 33,9480519 & 31,2426396 & 77 & \\
\hline \multirow[t]{2}{*}{ full } & 52,1197605 & 39,6774347 & 167 & \\
\hline & communication & communication (SD) & communication NOS & \\
\hline reduced & 7,08333333 & 20,322215 & 12 & \\
\hline partial & 63,6153846 & 22,2917715 & 13 & \\
\hline full & 60,8461538 & 66,9450598 & 13 & \\
\hline agreement & no agreement & no agreement (SD) & no agreement NOS & agreement Sig. \\
\hline reduced & 21,3333333 & 41,1579446 & 114 & 0 \\
\hline partial & 34,2948718 & 31,1898706 & 78 & \\
\hline \multirow[t]{2}{*}{ full } & 50,9314286 & 39,4796017 & 175 & \\
\hline & agreement & agreement (SD) & agreement NOS & \\
\hline reduced & 7,08333333 & 20,322215 & 12 & \\
\hline partial & 63,8333333 & 23,2685247 & 12 & \\
\hline full & 116,4 & 77,4486927 & 5 & \\
\hline fixed cost & no fixed cost & no fixed cost (SD) & no fixed cost NOS & fixed cost Sig. \\
\hline reduced & 21,7672414 & 40,9543453 & 116 & 0,00079336 \\
\hline partial & 33,4324324 & 31,5885713 & 74 & \\
\hline \multirow[t]{2}{*}{ full } & 47,6842105 & 31,2845139 & 152 & \\
\hline & fixed cost & fixed cost (SD) & fixed cost NOS & \\
\hline reduced & $-0,8$ & 8,12130258 & 10 & \\
\hline partial & 60,4375 & 22,3605866 & 16 & \\
\hline full & 80,25 & 72,818712 & 28 & \\
\hline symmetry & symmetry & symmetry (SD) & symmetry NOS & symmetry Sig. \\
\hline reduced & 21,5689655 & 39,3295175 & 58 & 0,04003939 \\
\hline partial & 39,372549 & 32,3276728 & 51 & \\
\hline \multirow[t]{2}{*}{ full } & 49,2913907 & 44,1783641 & 151 & \\
\hline & asymmetry & asymmetry (SD) & asymmetry NOS & \\
\hline reduced & 18,6176471 & 40,4685356 & 68 & \\
\hline partial & 36,7435897 & 31,42637 & 39 & \\
\hline
\end{tabular}




\begin{tabular}{|l|c|c|r|l|}
\hline full & 70,7586207 & 20,7547846 & 29 & \\
\hline capacity & unconstrained & unconstrained (SD) & unconstrained NOS & capacity Sig. \\
\hline reduced & 71,56 & 45,9547604 & 25 & 0 \\
\hline partial & 44,5 & 24,63737 & 52 & \\
\hline full & 57,738255 & 41,5450579 & 149 & \\
\hline & constrained & constrained (SD) & constrained NOS & \\
\hline reduced & 7,20792079 & 25,3957937 & 101 & \\
\hline partial & 29,6578947 & 38,2532643 & 38 & \\
\hline full & 28,7741935 & 36,0820451 & 31 & \\
\hline homogeneity & homogeneous & homogeneous (SD) & homogeneous NOS & homogeneity Sig. \\
\hline reduced & 6,8 & 27,5294947 & 105 & \\
\hline partial & 32,5324675 & 30,6545199 & 77 & \\
\hline full & 49,722973 & 44,4867665 & 148 & \\
\hline & heterogeneous & heterogeneous (SD) & heterogeneous NOS \\
\hline reduced & 85,8571429 & 22,3299926 & 21 & \\
\hline partial & 72 & 9,97496867 & 13 & \\
\hline full & 66,75 & 23,7459674 & 32 & \\
\hline
\end{tabular}

Table 65

Ex ante Information: Interaction Effects

(normalized deviation from the Walrasian equilibrium)

\section{Role of Feedback}

At the aggregate level, ex ante and feedback information have similar effects. The deviation from the Walrasian equilibrium is smallest if feedback is reduced. It increases with partial feedback, and it is highest with full feedback. As with ex ante information, the aggregate effect on deviations from the Nash equilibrium is less obvious. The only weakly significant result is in the ordinary coverage sample. It is the same as with the Walrasian equilibrium.

The distinction between partial and full is the same as with ex ante information. Feedback is full if subjects know their competitors' profits. It is partial if they only know their own profit. Again the category of reduced feedback is less strictly defined. It encompasses all situations where subjects get even less feedback.

\begin{tabular}{|l|r|r|r|r|r|}
\hline gross & CW & CW (SD) & CW NOS & CW ANOVA & $\begin{array}{l}\text { CW Kruskal- } \\
\text { Wallis }\end{array}$ \\
\hline reduced feedback & 6,51898734 & 30,5839998 & 79 & 0 & 0 \\
\hline partial feedback & 37,5426357 & 35,5630657 & 258 & & \\
\hline full feedback & 57,3963964 & 45,5725753 & 111 & & \\
\hline ordinary coverage & OC CW & OC CW (SD) & OC CW NOS & OC CW ANO- & \\
\hline reduced feedback & \multicolumn{1}{|c|}{$-0,57894737$} & 23,274716 & 57 & 0 & \\
\hline partial feedback & \multicolumn{1}{|c|}{22,4015748} & 31,2651893 & 127 & & \\
\hline full feedback & \multicolumn{1}{|l|}{40,4150943} & 25,5150287 & 53 & & \\
\hline treatment & T CW & T CW (SD) & T CW NOS & T CW ANOVA & \\
\hline reduced feedback & 5,33333333 & 58,7934237 & 6 & 0,1014702 & 0,238 \\
\hline partial feedback & 40,0285714 & 38,6678813 & 35 & & \\
\hline full feedback & 43,7368421 & 31,2940216 & 19 & & \\
\hline
\end{tabular}

Table 66

Feedback: Normalized Deviation from the Walrasian Equilibrium 


\begin{tabular}{|l|c|c|r|r|r|}
\hline treatment & T CN & T CN (SD) & T CN NOS & T CN ANOVA & \multicolumn{2}{l|}{ T CN Mann } \\
Whitney
\end{tabular}

Table 67

Feedback: Normalized Deviation from the Nash Equilibrium

(data from the gross and ordinary coverage samples insignificant)

\begin{tabular}{|l|r|r|r|r|r|}
\hline $\begin{array}{l}\text { ordinary cover- } \\
\text { age }\end{array}$ & OC NN & OC NN (SD) & OC NN NOS & OC NN ANOVA & $\begin{array}{l}\text { NN Kruskal Wal- } \\
\text { lis }\end{array}$ \\
\hline reduced feedback & $-2,66666667$ & 4,9244289 & 9 & 0,08515388 & 0,022 \\
\hline partial feedback & 46,4867257 & 252,181876 & 113 & & \\
\hline full feedback & \multicolumn{1}{|c|}{156,108696} & 413,03711 & 46 & & \\
\hline treatment & T NN & T NN (SD) & T NN NOS & T NN ANOVA & \\
\hline reduced feedback & $-27,8333333$ & 30,6099113 & 6 & 0,56795273 & 0,021 \\
\hline partial feedback & $-6,0625$ & 41,6505722 & 32 & & \\
\hline full feedback & $-3,66666667$ & 64,9823505 & 18 & & \\
\hline
\end{tabular}

Table 68

Feedback: Proportional Deviation from the Nash Equilibrium

(data from the gross sample insignificant)

As with ex ante information, feedback is mainly relevant through its interaction with other treatment variables. If buyers are human, going from reduced to partial feedback has a much smaller effect on collusion. If subjects are allowed to communicate, the effect of partial feedback is small, but the effect of full feedback is very large. The opposite is true if subjects cannot communicate. This pattern is even more pronounced if they are allowed to conclude an agreement. In a stranger design feedback is almost irrelevant. From this it follows that subjects use feedback mainly as a tool for backing collusion, not as one for learning how to interact. If interaction is simultaneous, feedback has the standard effects. In sequential interaction, however, collusion is high with reduced and with full feedback, and it is low with partial feedback.

If there is no fixed cost, feedback has the usual effects. With fixed cost, however, collusion is much higher with reduced and with full feedback. Although results are only weakly significant, it is also interesting to look at the interaction with surplus. If gains from collusion are high since most of the surplus is with consumers, feedback has the standard effects. With a symmetric distribution of the surplus between sellers and buyers, going from partial to full feedback no longer increases collusion. If most of the surplus is with producers anyhow, collusion even drops if one goes from partial to full feedback. Finally, if products are homogeneous, feedback has the usual effects. With substitutes, however, collusion goes down if one goes from partial to full feedback. 


\begin{tabular}{|c|c|c|c|c|}
\hline $\begin{array}{l}\text { computer/human } \\
\text { buyer }\end{array}$ & computer & computer (SD) & computer NOS & $\begin{array}{l}\text { computer/human } \\
\text { buyer Sig. }\end{array}$ \\
\hline reduced & 11,3589744 & 36,5257567 & 39 & 0,04509921 \\
\hline partial & 42,462963 & 34,0491918 & 216 & \\
\hline \multirow[t]{2}{*}{ full } & 57,3963964 & 45,5725753 & 111 & \\
\hline & human & human (SD) & human NOS & \\
\hline reduced & 1,8 & 22,9035883 & 40 & \\
\hline partial & 12,2380952 & 32,6300845 & 42 & \\
\hline full & 0 & 0 & 0 & \\
\hline communication & $\begin{array}{l}\text { no communica- } \\
\text { tion }\end{array}$ & $\begin{array}{l}\text { no communication } \\
\text { (SD) }\end{array}$ & $\begin{array}{l}\text { no communication } \\
\text { NOS }\end{array}$ & $\begin{array}{l}\text { communication } \\
\text { Sig. }\end{array}$ \\
\hline reduced & 6,43243243 & $\begin{array}{r}31,0527969 \\
\end{array}$ & 74 & 0,00488638 \\
\hline partial & 39,1213389 & 35,7197002 & 239 & \\
\hline \multirow[t]{2}{*}{ full } & 53,9354839 & 43,9032549 & 93 & \\
\hline & communication & communication (SD) & communication NOS & \\
\hline reduced & 7,8 & 25,2922913 & 5 & \\
\hline partial & 17,6842105 & 27,166263 & 19 & \\
\hline full & 75,2777778 & 51,0222622 & 18 & \\
\hline agreement & no agreement & no agreement (SD) & no agreement NOS & agreement Sig. \\
\hline reduced & 6,44871795 & $\begin{array}{r}30,7755374 \\
\end{array}$ & 78 & 0 \\
\hline partial & 38,942623 & 35,5777244 & 244 & \\
\hline \multirow[t]{2}{*}{ full } & 52,9278351 & 43,524717 & 97 & \\
\hline & agreement & agreement (SD) & agreement NOS & \\
\hline reduced & 12 & & ( & \\
\hline partial & 13,1428571 & 25,7797092 & 14 & \\
\hline full & 88,3571429 & 49,0174335 & 14 & \\
\hline partner/stranger & partner & partner (SD) & partner NOS & $\begin{array}{l}\text { partner/stranger } \\
\text { Sig. }\end{array}$ \\
\hline reduced & 4,85526316 & 29,7696507 & 76 & 0,004767 \\
\hline partial & 35,6637555 & 36,3951937 & 229 & \\
\hline \multirow[t]{2}{*}{ full } & 60,7710843 & 49,7477357 & 83 & \\
\hline & stranger & stranger (SD) & stranger NOS & \\
\hline reduced & 48,6666667 & 21,825062 & 3 & \\
\hline partial & 52,3793103 & 23,7793635 & 29 & \\
\hline full & 47,3928571 & 28,3957995 & 28 & \\
\hline sequence & simultaneous & simultaneous (SD) & simultaneous NOS & sequence Sig. \\
\hline reduced & 5,20779221 & $\begin{array}{r}29,8418364 \\
\end{array}$ & 77 & 0 \\
\hline partial & 39,965368 & 35,74619 & 231 & \\
\hline \multirow[t]{2}{*}{ full } & 51,4390244 & $\begin{array}{r}28,1609561 \\
\end{array}$ & 82 & \\
\hline & sequential & sequential (SD) & sequential NOS & \\
\hline reduced & 57 & 7,07106781 & 2 & \\
\hline partial & 16,8148148 & 26,4488433 & 27 & \\
\hline full & 74,2413793 & $\begin{array}{r}73,9399637 \\
\end{array}$ & 29 & \\
\hline fixed cost & no fixed cost & no fixed cost (SD) & no fixed cost NOS & fixed cost Sig. \\
\hline reduced & 6,11538462 & 30,5694784 & 78 & 0,01127443 \\
\hline partial & 36,5829384 & 36,3891205 & 211 & \\
\hline \multirow[t]{2}{*}{ full } & 50,3555556 & 28,1880966 & 90 & \\
\hline & fixed cost & fixed cost (SD) & fixed cost NOS & \\
\hline reduced & 38 & & 1 & \\
\hline partial & 41,8510638 & 31,586306 & 47 & \\
\hline full & 87,5714286 & 81,9008983 & 21 & \\
\hline surplus & producer & producer (SD) & producer NOS & surplus Sig. \\
\hline reduced & 6,75 & 29,0789156 & 4 & 0,06648389 \\
\hline partial & 15,7 & 53,1560595 & 10 & \\
\hline
\end{tabular}




\begin{tabular}{|c|c|c|c|c|}
\hline full & -2 & 15,5563492 & 2 & \\
\hline & symmetric & symmetric (SD) & symmetric NOS & \\
\hline reduced & 2,64102564 & 26,6916971 & 39 & \\
\hline partial & 31,8701299 & 31,8864559 & 77 & \\
\hline \multirow[t]{2}{*}{ full } & 29,125 & 23,5962568 & 16 & \\
\hline & consumer & consumer (SD) & consumer NOS & \\
\hline reduced & 10,6944444 & 34,6969076 & 36 & \\
\hline partial & 41,374269 & 35,3614984 & 171 & \\
\hline full & 64,4444444 & 46,6943471 & 90 & \\
\hline capacity & unconstrained & unconstrained (SD) & unconstrained NOS & capacity Sig. \\
\hline reduced & 24,0909091 & 49,451905 & 11 & 0,04256421 \\
\hline partial & 53,6241611 & 29,4896859 & 149 & \\
\hline \multirow[t]{2}{*}{ full } & 60,9659091 & 48,3346688 & 88 & \\
\hline & constrained & constrained (SD) & constrained NOS & \\
\hline reduced & 3,67647059 & 25,7887174 & 68 & \\
\hline partial & 15,559633 & 31,1984185 & 109 & \\
\hline full & 43,7391304 & 29,9927527 & 23 & \\
\hline homogeneity & homogeneous & homogeneous (SD) & homogeneous NOS & homogeneity Sig. \\
\hline reduced & 2,67123288 & 27,9285073 & 73 & \\
\hline partial & 30,793578 & 32,8133747 & 218 & 0 \\
\hline \multirow[t]{2}{*}{ full } & 53,3291139 & 52,0031364 & 79 & \\
\hline & heterogeneous & heterogeneous (SD) & heterogeneous NOS & \\
\hline reduced & 53,3333333 & 22,6686274 & 6 & \\
\hline partial & 74,325 & 26,4772641 & 40 & \\
\hline full & 67,4375 & 20,4654508 & 32 & \\
\hline
\end{tabular}

Table 69

Feedback: Interaction Effects

(normalized deviation from the Walrasian equilibrium)

\section{Neutral vs. Market Frame}

In oligopoly experiments, it is standard to tell subjects that they are sellers in a market. Some experimenters wondered whether the explicit frame has an impact on the degree of collusion. This is indeed the case, but in a surprising direction. If subjects are given the underlying game in a neutral frame, cooperation (collusion) rates go up substantially.

\begin{tabular}{|l|c|c|r|r|r|}
\hline gross & \multicolumn{1}{|l|}{ CW } & CW (SD) & CW NOS & CW ANOVA & \multicolumn{2}{l|}{$\begin{array}{l}\text { WW Mann- } \\
\text { Whitney }\end{array}$} \\
\hline market frame & 35,8543046 & 40,9771246 & 453 & 0,0182041 & 0,004 \\
\hline neutral frame & 57,2380952 & 24,9116534 & 21 & & \\
\hline ordinary coverage & OC CW & OC CW (SD) & OC CW NOS & OC CW ANOVA & \\
\hline market frame & 18,814346 & 30,5160302 & 237 & & 0 \\
\hline neutral frame & 50,0714286 & 22,1062619 & 14 & & \\
\hline
\end{tabular}

Table 70

Frame: Normalized Deviation from the Walrasian Equilibrium

(no treatment data available) 


\begin{tabular}{|l|l|l|r|l|l|}
\hline gross & CN & CN (SD) & CN NOS & CN ANOVA & $\begin{array}{l}\text { CN Mann- } \\
\text { Whitney }\end{array}$ \\
\hline market frame & $-4,07651715$ & 78,9314347 & 379 & 0,05460168 & 0,004 \\
\hline neutral frame & 29,3809524 & 39,0556989 & 21 & & \\
\hline
\end{tabular}

Table 71

Frame: Normalized Deviation from the Nash Equilibrium

(data from the ordinary coverage sample insignificant, no treatment data available all data on the NN index insignificant, no treatment data on that index)

\section{Sensitivity of Collusion to Buyer Activity}

\section{Computer vs. Human Buyers}

Oligopoly experiments are designed to learn more about the behaviour of sellers. This explains that buyers are usually replaced by a computer. This computer is programmed as a non-strategic actor. It simply represents the demand curve. This apparently innocent way of saving experimental resources, and of gaining full control over the opposite market side, has a dramatic influence on collusion. When subjects know that they are playing against human buyers, collusion rates plummet.

\begin{tabular}{|l|c|c|r|r|r|}
\hline gross & CW & CW (SD) & CW NOS & CW ANOVA & $\begin{array}{l}\text { CW Mann- } \\
\text { Whitney }\end{array}$ \\
\hline computer buyer & 42,9770992 & 40,0226592 & 393 & & 0 \\
\hline human buyer & 6,60465116 & 28,256089 & 86 & & \\
\hline ordinary coverage & OC CW & OC CW (SD) & OC CW NOS & OC CW ANOVA & \\
\hline computer buyer & 27,1491713 & 29,8063167 & 181 & & 0 \\
\hline human buyer & 3,46666667 & 26,957591 & 75 & & \\
\hline
\end{tabular}

Table 72

Human vs. Computer Buyers: Normalized Deviation from the Walrasian Equilibrium (no treatment data available, data on $\mathrm{CN}$ and $\mathrm{NN}$ index insignificant)

\section{Sensitivity of Collusion to the Trading Institution}

Trading institutions matter. This is one of the most robust findings from the experimental literature on oligopoly (see only Ketcham, Smith et al. 1984). In essence, this is a statement about the kind and the degree of buyer influence. The majority of oligopoly experiments uses the posted offer institution. Each seller is free to post a price. Buyers shop around, or efficient rationing does the shopping for them. This rule makes buyers almost passive. Consequently, collusion is 
highest. The effect becomes even stronger in the "posted Diamond“ treatment. ${ }^{13}$ This treatment is meant to test the model by (Diamond 1971). This is implemented by making shopping costly for buyers. All other trading institutions yield collusion rates far below this level. If participants at both sides of the market have an opportunity to submit a sealed bid, there is still a small amount of collusion. If they negotiate individually, collusion is already close to zero. In a double auction, average collusion falls below the Walrasian prediction. Under this rule, every higher bid by a buyer replaces all previous lower bids. Likewise every lower bid by a seller replaces all previous higher ones.

\begin{tabular}{|c|c|c|c|c|c|}
\hline gross & $\mathrm{CW}$ & CW (SD) & CW NOS & CW ANOVA & $\begin{array}{l}\text { CW Kruskal- } \\
\text { Wallis } \\
\end{array}$ \\
\hline other trading institution & 9,1875 & 29,200956 & 16 & 0 & 0 \\
\hline posted & 48,6666667 & 38,414253 & 339 & & \\
\hline posted Diamond & 45,1875 & 24,6339028 & 16 & & \\
\hline sealed bid & 4,52941176 & 29,1099589 & 17 & & \\
\hline negotiation & 1,28571429 & 11,5653898 & 14 & & \\
\hline double auction & $-0,06493506$ & 26,19579 & 77 & & \\
\hline ordinary coverage & $\mathrm{OC} \mathrm{CW}$ & $\mathrm{OC} \mathrm{CW}(\mathrm{SD})$ & OC CW NOS & $\begin{array}{l}\text { OC CW } \\
\text { ANOVA }\end{array}$ & \\
\hline other trading institution & 2,625 & 39,9032312 & 8 & 0 & c \\
\hline posted & 35,4485294 & 24,447622 & 136 & & \\
\hline posted Diamond & 39 & 31,0207304 & 8 & & \\
\hline sealed bid & 4,52941176 & 29,1099589 & 17 & & \\
\hline negotiation & 1,28571429 & 11,5653898 & 14 & & \\
\hline double auction & $-1,02739726$ & 26,5015579 & 73 & & \\
\hline treatment & T CW & T CW (SD) & T CW NOS & T CW ANOVA & \\
\hline other trading institution & 13,1666667 & 12,576433 & 6 & 0,00116815 & 0,015 \\
\hline posted & 18,2380952 & 19,0050119 & 21 & & \\
\hline posted Diamond & 56,75 & 22,3960562 & 4 & & \\
\hline sealed bid & 4,52941176 & 29,1099589 & 17 & & \\
\hline negotiation & 1,33333333 & 18,3393929 & 3 & & \\
\hline double auction & 3,66666667 & 18,8439709 & 15 & & \\
\hline
\end{tabular}

Table 73

Trading Institution: Normalized Deviation from the Walrasian Equilibrium

\begin{tabular}{|c|c|c|c|c|c|}
\hline gross & $\mathrm{CN}$ & $\mathrm{CN}(\mathrm{SD})$ & CN NOS & CN ANOVA & $\begin{array}{l}\text { CN Kruskal- } \\
\text { Wallis }\end{array}$ \\
\hline other trading institution & $-139,2$ & 307,809754 & 10 & 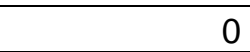 & 0,008 \\
\hline posted & 2,66043614 & 63,6344538 & 321 & & \\
\hline posted Diamond & 3,92857143 & 44,8492591 & 14 & & \\
\hline negotiation & $-4,07692308$ & 10,4360077 & 13 & & \\
\hline double auction & $-7,93478261$ & 28,7992301 & 46 & & \\
\hline ordinary coverage & $\mathrm{OC} \mathrm{CN}$ & $\mathrm{OC} \mathrm{CN} \mathrm{(SD)}$ & OC CN NOS & $\begin{array}{l}\text { OC CN } \\
\text { ANOVA }\end{array}$ & \\
\hline other trading institution & -249 & 366,561318 & 6 & 0 & 0,003 \\
\hline posted & 4,55462185 & 33,8645601 & 119 & & \\
\hline posted Diamond & 8,5 & 5,71839138 & 6 & & \\
\hline negotiation & $-4,07692308$ & 10,4360077 & 13 & & \\
\hline
\end{tabular}

13 Except for the CW index in the gross sample, where it is slightly below the value for ordinary posted offer experiments, and far above all the results for all other trading institutions. 


\begin{tabular}{|l|r|c|r|r|r|}
\hline double auction & $-9,8372093$ & 28,7409864 & 43 & & \\
\hline treatment & T CN & T CN (SD) & T CN NOS & T CN ANOVA & \\
\hline posted & 2,61538462 & 33,0493027 & 13 & 0,01841942 & 0,022 \\
\hline posted Diamond & 55,5 & 22,6936114 & 4 & & \\
\hline negotiation & -9 & 5,65685425 & 2 & & \\
\hline double auction & $-26,1428571$ & 51,6540691 & 7 & & \\
\hline
\end{tabular}

Table 74

Trading Institution: Normalized Deviation from the Nash Equilibrium

\begin{tabular}{|c|c|c|c|c|c|}
\hline gross & NN & NN (SD) & NN NOS & NN ANOVA & $\begin{array}{l}\text { NN Kruskal- } \\
\text { Wallis }\end{array}$ \\
\hline $\begin{array}{l}\text { other trading } \\
\text { institution }\end{array}$ & $-85,3333333$ & 73,9963963 & 6 & 0 & 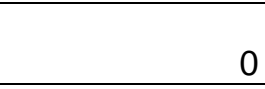 \\
\hline posted & 38,9903846 & 173,147159 & 312 & & \\
\hline $\begin{array}{l}\text { posted Dia- } \\
\text { mond }\end{array}$ & 271,25 & 613,814576 & 16 & & \\
\hline negotiation & $-1,61538462$ & 7,03015483 & 13 & & \\
\hline double auction & 4,725 & 43,3814255 & 40 & & \\
\hline $\begin{array}{l}\text { ordinary cov- } \\
\text { erage }\end{array}$ & OC NN & OC NN (SD) & OC NN NOS & OC NN ANOVA & \\
\hline $\begin{array}{l}\text { other trading } \\
\text { institution }\end{array}$ & $-85,3333333$ & 73,9963963 & 6 & 0 & 0,011 \\
\hline posted & 76,6869565 & 273,718429 & 115 & & \\
\hline $\begin{array}{l}\text { posted Dia- } \\
\text { mond }\end{array}$ & 488 & 836,420776 & 8 & & \\
\hline negotiation & $-1,61538462$ & 7,03015483 & 13 & & \\
\hline double auction & 4,72972973 & 45,1470736 & 37 & & \\
\hline treatment & T NN & T NN (SD) & T NN NOS & T NN ANOVA & \\
\hline posted & 56,9230769 & 154,47139 & 13 & 0,91419845 & 0,094 \\
\hline $\begin{array}{l}\text { posted Dia- } \\
\text { mond }\end{array}$ & 63 & 26,0895892 & 4 & & \\
\hline negotiation & $-1,5$ & 0,70710678 & 2 & & \\
\hline double auction & 33,4285714 & 104,485816 & 7 & & \\
\hline
\end{tabular}

Table 75

Trading Institution: Proprotional Deviation from the Nash Equilibrium

\section{Collusion under Conditions of Demand Inertia}

In reality, demand is hardly ever perfectly elastic. Buyers hold to their buying habits as long as a competing offer is not clearly more attractive in qualitative terms, or substantially cheaper. Experimenters have tested markets with such demand inertia. The result is as one would expect. Market outcomes are further away from both the Walrasian and the Nash predictions. 


\begin{tabular}{|l|r|r|r|r|r|}
\hline ordinary coverage & OC CW & OC CW (SD) & OC CW NOS & OC CW ANOVA & $\begin{array}{l}\text { CW Mann Whit- } \\
\text { ney }\end{array}$ \\
\hline no demand inertia & 17,0877193 & 30,4451732 & 228 & 0 & 0 \\
\hline demand inertia & 45,6428571 & 21,6798495 & 28 & & \\
\hline treatment & T CW & T CW (SD) & T CW NOS & T CW ANOVA & \\
\hline no demand inertia & 34 & 11,8039541 & 4 & 0,28745551 & 0,141 \\
\hline demand inertia & 45,2666667 & 20,2006032 & 30 & & \\
\hline
\end{tabular}

Table 76

Demand Inertia: Normalized Deviation from the Walrasian Equilibrium

(data from gross sample insignificant)

\begin{tabular}{|l|r|c|r|r|r|}
\hline ordinary coverage & \multicolumn{1}{l|}{ OC CN } & OC CN (SD) & OC CN NOS & OC CN ANOVA & \multicolumn{2}{l|}{$\begin{array}{l}\text { CN Mann Whit- } \\
\text { ney }\end{array}$} \\
\hline no demand inertia & $-11,2981366$ & 86,0650077 & 161 & 0,09737016 & 0,001 \\
\hline demand inertia & 17 & 19,3845299 & 26 & & \\
\hline treatment & T CN & T CN (SD) & T CN NOS & T CN ANOVA & \\
\hline no demand inertia & $-16,25$ & 46,5429909 & 4 & 0,06294287 & 0,347 \\
\hline demand inertia & 10,75 & 22,7899019 & 28 & & \\
\hline
\end{tabular}

Table 77

Demand Inertia: Normalized Deviation from the Nash Equilibrium

(data from gross sample insignificant)

\begin{tabular}{|c|c|c|c|c|c|}
\hline gross & NN & $\mathrm{NN}(\mathrm{SD})$ & NN NOS & NN ANOVA & $\begin{array}{l}\text { NN Mann- } \\
\text { Whitney }\end{array}$ \\
\hline no demand inertia & 31,2165242 & 164,653693 & 351 & 0,00144229 & 0 \\
\hline demand inertia & 144,555556 & 420,534112 & 36 & & \\
\hline ordinary coverage & OC NN & OC NN (SD) & OC NN NOS & OC NN ANOVA & \\
\hline no demand inertia & 49,8476821 & 243,190865 & 151 & 0,04129457 & 0 \\
\hline demand inertia & 172,785714 & 474,662637 & 28 & & \\
\hline treatment & T NN & T NN (SD) & T NN NOS & T NN ANOVA & \\
\hline no demand inertia & 44 & 0 & 2 & 0,7102944 & 0,777 \\
\hline demand inertia & 172,035714 & 474,71032 & 28 & & \\
\hline
\end{tabular}

Table 78

Demand Inertia: Proportional Deviation from the Nash Equilibrium

\section{Conclusion}

Experimental research on oligopoly is rich, but it is not complete. There is one main effect that has not been tested: increasing returns to scale, or a supply curve with a negative slope. Also, nobody has ever given up the implicit assumption that barriers to entry are prohibitively high. Since both is frequent in practice, it would be worthwhile testing.

There are many more white marks on the map when it comes to the interaction between several parameters characterising an oligopoly market. This study makes them visible in two different 
dimensions. The first one is straightforward. To the best of our knowledge, quite a number of combinations of features have simply not been studied. Among the lacunae are the following: there is no experiment testing substitutes in a double auction or with human buyers. Nobody has explored the effect of a positive fixed cost in a double auction or in a stranger design. There is much less research on constant demand, compared to demand decreasing in quantity. Among the missing combinations is again the double auction, asymmetry, reduced feedback or a chance to conclude an agreement. Supply decreasing in quantity has not been studied in a stranger design. There is relatively little work on markets where the majority of the surplus is with producers. This has not been studied in a market of two, with a stranger design, with substitutes or with sequential interaction.

Nobody has given strangers a chance to communicate or to conclude an agreement. The opportunity to agree has also not been tested in markets of a larger size than four, if there is advance production, or if the majority of the surplus is with producers. There is no study testing full ex ante information in a double auction. Partial ex ante information has not been combined with sequential interaction or with negotiation. Human buyers have not been introduced in experiments using a stranger design, giving subjects full feedback, leaving capacity unconstrained, or differentiating products. In many contexts the double auction has not been used. There is no study imposing it in duopoly or triopoly markets. Subjects have never received full ex ante information. There has been no demand inertia. Products have always been homogeneous. No seller has had power. Experimenters have always used a fixed partner design. Capacity has always been constrained.

It has been one of the purpose of this study to make data on interaction effects available, although no experimenter has explicitly tested for them. This, however, only works if, in this meta study, the effects are significant. For reasons of space, not all of them could be reported. But many of the potential interaction effects are simply not significant. From a policy perspective, it for instance would be desirable to know more about the effect of experience on the likelihood that firms will beat the Nash equilibrium. Although a crosstable shows that there is data on many combinations, only one of the effects is significant. If one of the subjects has power, experience pushes collusion high above the Nash equilibrium.

\begin{tabular}{|l|r|c|r|r|}
\hline & no power & no power (SD) & no power NOS & power Sig. \\
\hline no experience & 3,19626168 & 51,1824138 & 321 & 0,012 \\
\hline experience & 12,8703704 & 38,3317427 & 54 & \\
\hline & power & power (SD) & power NOS & \\
\hline no experience & $-100,555556$ & 215,453785 & 27 & \\
\hline experience & 46,5 & 3,53553391 & 2 & \\
\hline
\end{tabular}

Table 79

Experience - Power: Interaction Effect

(normalized deviation from the Nash equilibrium) 
A closer look at the data demonstrates why further research on interaction effects is a desideratum. In the critical cell, the effect is based on just two observations. It has only become significant since the impact of experience is dramatic. This implies that explicit tests of interaction effects should be able to establish many more of them. This study, and the data bank behind it, may help experimenters build expectations about the direction of the interaction effects, and where they are particularly likely to be found. 


\section{References}

Alger, DAN (1987). "Laboratory Tests of Equilibrium Predictions with Disequilibrium Data.“ Review of Economic Studies 54: 105-145.

Allen, Beth and Martin Hellwig (1986a). Bertrand-Edgeworth Oligopoly in Large Markets.“ Review of Economic Studies 53: 175-204.

Allen, Beth and Martin Hellwig (1986b). "Price-Setting Firms and the Oligopolistic Foundations of Perfect Competition.“ American Economic Association Papers and Proceedings 76: 387-392.

Altavilla, Carlo, Luigi Luini and Patrizia Sbriglia (2005). Social Learning in Market Games http://www.econ-pol.unisi.it/labsi/labsi_paper/labsi3.pdf.

Anderhub, Vital, Werner GÜth, Ulrich Kamecke and Hans-Theo Normann (2003). "Capacity Choices and Price Competition in Experimental Markets.“ Experimental Economics 6: 27-52.

Aumann, Robert J. and Lloyd S. Shapley (1994). Long Term Competition - A Game Theoretic Analysis. Collected Papers I. Robert J. Aumann. Cambridge, MIT Press: 395-409.

Benson, Bruce L. and M.D. FAminow (1988). "The Impact of Experience on Prices and Profits in Experimental Duopoly Markets.“ Journal of Economic Behavior \& Organization 9: 345365.

BERTRAnd, Joseph Louis Francois (1883). “Théorie mathématique de la richesse sociale par León Walras. Recherches sur les principes mathématiques de la théorie des richesses par Augustin Cournot.“ Journal des savants 67: 499-508.

BORTZ, JÜRGEN (2005). Statistik für Human- und Sozialwissenschaftler. Heidelberg, Springer.

Bosch-Domènech, Antoni and NicolaAs J. VRiend (2003). "Imitation of Successful Behavior in Cournot Markets.“ Economic Journal 113: 495-524.

Capra, Monica C., Jacob K. Goeree, Rosario Gomez and Charles A. Holt (2002). “Learning and Noisy Equilibrium Behavior in an Experimental Study of Imperfect Price Competition.“ International Economic Review 43: 613-636.

Cason, Timothy N. and Douglas D. Davis (1995). "Price Communication in a Multi-Market Context. An Experimental Investigation.“ Review of Industrial Organization 10: 769-787.

Chamberlin, Edward (1933). The Theory of Monopolistic Competition. Cambridge,, Harvard University Press. 
Cournot, Antoine-Augustin (1838). Recherches sur les principes mathématiques de la théorie des richesses. Paris,, Libraririe des sciences politiques et sociales M. Riveáre \& cie.

CoX, James C. and MARK WALKer (1998). “Learning to Play Cournot Duopoly Strategies.“ Journal of Economic Behavior \& Organization 36: 141-161.

Crawford, VinCENT (1998). “A Survey of Experiments on Communication via Cheap Talk.“ Journal of Economic Theory 78(2): 286-298.

Daughety, Andrew F. and Robert Forsythe (1987). "The Effects of Industry-Wide Price Regulation on Industrial Organization.“ Journal of Law, Economics and Organization 3: 397-434.

Davidson, Carl and Raymond J. Deneckere (1986). "Long-Run Competition in Capacity, Short-Run Competition in Price, and the Cournot Model.“ Rand Journal of Economics 17: 404-415.

Davis, Douglas D. and Charles A. Holt (1993). Experimental Economics. Princeton, NJ, Princeton Univ. Press.

Davis, Douglas D., Robert J. Reilly and Bart Wilson (2003). "Cost Structures and Nash Play in Repeated Cournot Games.“ Experimental Economics 6: 209-226.

Davis, Douglas and Bart Wilson (2005). "Differentiated Product Competition and the Antitrust Logit Model. An Experimental Analysis.“ Journal of Economic Behavior \& Organization 57: 89-113.

DiAmond, Peter (1971). “A Model of Price Adjustments.“ Journal of Economic Theory 3: 156168.

Edgeworth, Francis (1897). “La Teoria Pura del Monopolio.“ Giornale degli Economisti 40: 13-31.

FouraKer, LAWREnCE E. and Sidney Siegel (1963). Bargaining Behavior. New York,, McGraw-Hill.

Friedman, DANiEL (1969). “On Experimental Research in Oligopoly.“ Review of Economic Studies 36: 399-415.

Friedman, Milton (1953). Essays in Positive Economics. [Chicago], University of Chicago Press.

Fudenberg, Drew and Jean Tirole (1991). Game Theory. Cambridge, Mass., MiT Press.

Hays, WiLliam LeE (1994). Statistics. Fort Worth, Harcourt College Publishers. 
Hoggatt, Austin Curwood (1959). “An Experimental Business Game.“ Behavioral Science 4: 192-203.

Holt, Charles A. (1995). Industrial Organization. A Survey of Laboratory Research. Handbook of Experimental Economics. John H. Kagel und Alvin E. Roth. Princeton, Princeton University Press: 349-443.

Holt, Charles A. and Fernando Solis-Soberon (1992). "The Calculation of Equilibrium Mixed Strategies in Posted-Offer Auctions.“ Research in Experimental Economics 5: 189228.

Huck, Steffen, Hans-Theo Normann and Jörg Oechssler (2004). "Two are Few and Four are Many. Number Effects in Experimental Oligopolies.“ Journal of Economic Behavior \& Organization 53: 435-446.

IsAaC, R. MARK, VALÉRIE RAMEY and ARlington W. Williams (1984). "The Effects of Market Organization on Conspiracy in Restraints of Trade.“ Journal of Economic Behavior \& Organization 5: 191-222.

Ketcham, Jon, Vernon L. Smith and Arlington W. Williams (1984). “A Comparison of Posted-Offer and Double-Auction Pricing Institutions.“ Review of Economic Studies 51: 595-614.

Kreps, David M. and Jose Alexandre Scheinkman (1983). "Quantity Precommitment and Bertrand Competition Yields Cournot Outcomes.“ Bell Journal of Economics 14: 326-337.

LuPi, PAOlO and PAtrizia Sbriglia (2003). "Exploring Human Behaviour and Learning in Experimental Cournot Settings.“ Rivista Internazionale di Studi Sociali 51: 373-397.

NAgel, Rosemarie and NicolaAs J. VRiend (1999a). “An Experimental Study of Adaptive Behaviour in an Oligopolistic Market Game.“ Journal of Evolutionary Economics 9: 27-65.

Nagel, Rosemarie and NicolaAs J. VRiend (1999b). “Inexperienced and Experienced Players in an Oligopolistic Market Game with Minimal Information.“ Industrial and Corporate Change 8: 41-65.

Offerman, Theo, Jan Potters and Joep Sonnemans (2002). "Imitation and Belief Learning in an Oligopoly Experiment.“ Review of Economic Studies 69: 973-997.

Plott, Charles R. (1982). "Industrial Organization. Theory and Experimental Economics.“ Journal of Economic Literature 20: 1485-1527.

Plott, Charles R. (1989). An Updated Review of Industrial Organization. Applications of Experimental Methods. Handbook of Industrial Organization. Richard Schmalensee und Robert D. Willig. Amsterdam, North Holland: 1109-1176. 
Rassenti, Stephen, Stanley S. Reynolds, Vernon L. Smith and Ferenc Szidarovszky (2000). "Adaptation Convergence of Behaviour in Repeated Experimental Cournot Games.“ Journal of Economic Behavior \& Organization 41: 117-146.

Selten, Reinhard (1973). “A Simple Model of Imperfect Competition, Where Four Are Few and Six Are Many.“ International Journal of Game Theory 2: 141-201.

SELten, ReInHARD (1978). “The Chain Store Paradox.“ Theory and Decision 9: 127-159.

Selten, Reinhard and Heinz Sauermann (1959). "Ein Oligopolexperiment.“ Zeitschrift für die gesamte Staatswissenschaft 115: 427-471.

Selten, Reinhard and Rolf Stoecker (1986). "End Behavior in Sequences of Finite Prisoner's Dilemma Supergames.“ Journal of Economic Behavior \& Organization 7: 47-70.

SHERman, Roger (1969). "Risk Attitude and Cost Variability in a Capacity Choice Experiment.“ Review of Economic Studies 36: 453-466.

Shubik, Martin, Gerrit Wolf and Scott Lockhart (1971). “An Artificial Player for a Business Market Game.“ Simulation and Games 2: 27-43.

Smith, Vernon L. (1976). "Experimental Economics: Induced Value Theory.“ American Economic Review Papers and Proceedings 66: 274-279.

Stackelberg, HeINRICH vON (1934). Marktform und Gleichgewicht. Wien und Berlin,, J. Springer.

Suetens, SigRID (2004). R\&D Cooperation in Oligopoly with Spillovers. An Experimental Economics Approach. Literature Review

http://www.ua.ac.be/download.aspx?c=*TEWHI\&n=14378\&ct=009844\&e=34935.

Suetens, Sigrid and Jan PotTers (2005). Bertrand Colludes More Than Cournot http://ideas.repec.org/p/ant/wpaper/2005037.html.

TIRole, JEAN (1988). The Theory of Industrial Organization. Cambridge, Mass., MIT Press. 


\section{papers included in the meta-study}

ABBinK, KLAUS and JORDi BRANDTS (2003). 24

http://www.iae-csic.uab.es/brandts/pub/24-revised.pdf.

AbBinK, Klaus and JoRdi BrandTs (2005a). Collusion in Growing and Shrinking Markets. Empirical Evidence from Experimental Duopolies http://www.nottingham.ac.uk/economics/cedex/papers/2005-03.pdf.

AbBinK, Klaus and Jordi Brandts (2005b). "Price Competition under Cost Uncertainty. A Laboratory Analysis.“ Economic Inquiry 43: 636-648.

Abrams, ERic, Martin Sefton and Abdullah Yavas (2000). “An Experimental Comparison of two Search Models.“ Economic Theory 16: 735-749.

Altavilla, Carlo, Luigi Luini and Patrizia Sbriglia (2005). Social Learning in Market Games http://www.econ-pol.unisi.it/labsi/labsi_paper/labsi3.pdf.

Anderhub, Vital, Werner GÜth, Ulrich KamecKe and Hans-Theo Normann (2003). “Capacity Choices and Price Competition in Experimental Markets.“ Experimental Economics 6: $27-52$.

Bailey, JefF and Stuart Mestelman (2002). Testing and Verifying Cournot and Bertrand Theories of Duopoly Markets

Bosch-Domènech, Antoni and NicolaAs J. VRiend (2003). "Imitation of Successful Behavior in Cournot Markets.“ Economic Journal 113: 495-524.

BRANDTS, JoRdi and PABLO GuILlÉN (2004). Collusion into Fights in an Experiment with PriceSetting Firms and Production in Advance http://pareto.uab.es/wp/2004/61804.pdf.

Brown Kruse, Jamie, Stephen Rassenti, Stanley S. Reynolds and Vernon L. Smith (1994). "Bertrand-Edgeworth Competition in Experimental Markets.“ Econometrica 62: 343-371.

Capra, Monica C., Jacob K. Goeree, Rosario Gomez and Charles A. Holt (2002). "Learning and Noisy Equilibrium Behavior in an Experimental Study of Imperfect Price Competition.“ International Economic Review 43: 613-636.

CARLson, John A. (1967). “The Stability of an Experimental Market with a Supply-Response Lag.“ Southern Economic Journal 33: 305-321.

Cason, Timothy N. and Douglas D. Davis (1995). "Price Communication in a Multi-Market Context. An Experimental Investigation.“ Review of Industrial Organization 10: 769-787. 
Cason, Timothy N. and Daniel Friedman (2003). "Buyer Search and Price Dispersion. A Laboratory Study.“ Journal of Economic Theory 112: 232-260.

CoOK, William D. and E.C.H. Veendorp (1975). "Six Markets in Search of an Auctioneer.“ Canadian Journal of Economics 8: 238-257.

CRÖSSMANN, HEINZ JÜRGEN (1982). Entscheidungsverhalten auf unvollkommenen Märkten. Frankfurt, Barudio.

DAughety, ANDREW F. and ROBERT FORSYTHE (1987). Industrywide Regulation and the Formation of Reputations. A Laboratory Analysis. Public Regulation. New Perspectives on Institutions and Policies. Elizabeth E. Bailey. Cambridge, Mass., MIT Press: 347-398.

DAVIS, Douglas (1996). “Consumer Search Costs and Market Performance.“ Economic Inquiry 34: 133-151.

DAVIS, Douglas (1998). “Conspiracies and Secret Discounts in Laboratory Markets.“ Economic Journal 108: 736-756.

Davis, Douglas D. (1999). "Advanced Production and Cournot Outcomes. An Experimental Investigation.“ Journal of Economic Behavior \& Organization 40: 59-79.

Davis, Douglas D. and ArLington W. Williams (1986). "The Effects of Rent Asymmetries in Posted Offer Markets.“ Journal of Economic Behavior \& Organization 7: 303-316.

Davis, Douglas D. and Bart Wilson (2003). Horizontal Merger, Strategic Buyers and Fixed Cost Synergies. An Experimental Investigation http://www.people.vcu.edu/ dddavis/working\%20papers/dw0803.pdf.

Davis, Douglas and Charles A. Holt (1994). "Market Power and Mergers in Laboratory

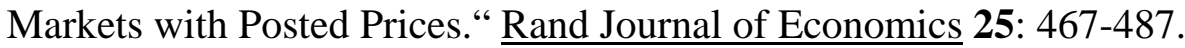

Davis, Douglas and Bart Wilson (2000). "Firm-Specific Cost Savings and Market Power.“ Economic Theory 16: 545-565.

Dixon, Huw D., Patrizia Sbriglia and ERnesto Somma (2003). Learning to Collude. An Experiment in Convergence and Equilibrium Selection in Oligopoly http://papers.ssrn.com/sol3/papers.cfm?abstract_id=877231.

Dolbaer, F.G., L.B. Lave, G. Bowman, A. Lieberman, E. Prescott, F. Ruetter and R. SHERMAN (1968). "Collusion in Oligopoly. An Experiment on the Effect of Numbers and Information.“ Quarterly Journal of Economics 82: 240-259.

Dufwenberg, Martin and Uri Gneezy (2000). “Price Competition and Market Concentration. An Experimental Study.“ International Journal of Industrial Organization 18: 7-22. 
Dufwenberg, Martin, Uri Gneezy, Jacob K. Goeree and Rosemarie Nagel (2002). Price Floors and Competition http://www.ne.su.se/paper/wp02_13.pdf.

Dugar, Subhasish (2005). Do Price-Matching Guarantees Facilitate Tacit Collusion? An Experimental Study http://ssrn.com/abstract $=655392$.

Dugar, SubHasish and TodD Sorensen (2005). Hassle Costs, Price-Matching Guarantees and Price Competition. An Experiment http://ssrn.com/abstract=727324.

FAJfAR, PABLO (2005). Information and Competition in Cournot's Model. Evidence from the Laboratory http://ssrn.com/abstract=884231.

Feinberg, Robert M. and Thomas A. Husted (1993). “An Experimental Test of Discount-Rate Effects on Collusive Behaviour in Duopoly Markets.“ Journal of Industrial Economics 41: 153-160.

Feinberg, Robert M. and Roger SHERman (1988). “Mutual Forbearance under Experimental Conditions.“ Southern Economic Journal 54: 985-993.

Fonseca, Miguel A., Steffen Huck and Hans-Theo Normann (2005). "Playing Cournot Although They Shouldn't.“ Economic Theory 25: 669-677.

Fonseca, Miguel A., Wieland Müller and Hans-Theo Normann (2005). Endogenous Timing in Duopoly. Experimental Evidence http://greywww.kub.nl:2080/greyfiles/center/2005/doc/77.pdf.

Fouraker, LAWRence E. and Sidney Siegel (1963). Bargaining Behavior. New York, McGraw-Hill.

Friedman, James W. and Austin Curwood Hoggatt (1980). An Experiment in Noncooperative Oligopoly. Greenwich, Conn., JAI Press.

García Gallego, Aurora (1998). “Oligopoly Experimentation of Learning with Simulated Markets.“ Journal of Economic Behavior \& Organization 35: 333-355.

García Gallego, Aurora and Nikolaos Georgantzis (2001). "Multiproduct Activity in an Experimental Differentiated Oligopoly.“ International Journal of Industrial Organization 19: 493-518.

Goodwin, David and Stuart Mestelman (2003). Advance Production Duopolies and Posted Prices or Market-Clearing Prices http://socserv.mcmaster.ca/econ/mceel/papers/KSDuopAllAug03.pdf.

Grether, David M. and Charles R. Plott (1984). "The Effects of Market Practices in Oligopolistic Markets. An Experimental Examination of the Ethyl Case.“ Economic Inquiry 22: 479-507. 
GÜth, Werner, Wieland MÜller and Yossi Spiegel (2006). “Noisy Leadership. An Experimental Approach.“ Games and Economic Behavior forthcoming.

Harstad, Ronald, Stephen Martin and Hans-Theo Normann (1998). Intertemporal Pricing Schemes. Experimental Tests of Consciously Parallel Behaviour in Oligopoly. Applied Industrial Economics. Louis Phlips. Cambridge, Cambridge University Press: 123-151.

Hoffman, Elizabeth and Charles R. Plott (1981). "The Effect of Intertemporal Speculation on the Outcomes in Seller Posted Offer Auction Markets.“ Quarterly Journal of Economics 96: $223-242$.

Hoggatt, Austin Curwood (1959). “An Experimental Business Game.“ Behavioral Science 4: 192-203.

Hoggatt, Austin Curwood (1969). "Response of Paid Student Subjects to Differential Behaviour of Robots in Bifurcated Duopoly Games.“ Review of Economic Studies 36: 417-432.

Holt, Charles A. (1985). "An Experimental Test of the Consistent-Conjectures Hypothesis.“ American Economic Review 75: 314-325.

Holt, Charles A. and Anne P. Villamil (1986). "A Laboratory Experiment with a SingePerson Cobweb.“ Atlantic Economic Journal 14/2: 51-54.

Hong, James T. and Charles R. Plott (1982). "Rate Filing Policies for Inland Water Transportation. An Experimental Approach.“ Bell Journal of Economics 13: 1-19.

Huck, Steffen, Wieland Müller and Hans-Theo Normann (2001). "Stackelberg Beats Cournot. On Collusion and Efficiency in Experimental Markets.“ Economic Journal 111: 749-765.

Huck, Steffen, Wieland Müller and Hans-Theo Normann (2002). “To Commit or Not to Commit. Endogenous Timing in Experimental Duopoly Markets.“ Games and Economic Behavior 38: 240-264.

Huck, Steffen, Wieland Müller and Hans-Theo Normann (2004). "Strategic Delegation in Experimental Markets.“ International Journal of Industrial Organization 22: 561-574.

Huck, StefFen, HAns-Theo Normann and Jörg Oechssler (1999). “Learning in Cournot Oligopoly. An Experiment.“ Economic Journal 109: C80-C95.

Huck, Steffen, Hans-Theo Normann and Jörg Oechssler (2000). “Does Information About Competitor's Actions Increase or Decrease Competition in Experimental Oligopoly Markets?“ International Journal of Industrial Organization 18: 39-57.

Huck, Steffen, Hans-Theo Normann and Jörg Oechssler (2001). "Market Volatility and Inequality in Earnings. Experimental Evidence.“ Economics Letters 70: 363-368. 
Huck, Steffen, Hans-Theo Normann and Jörg Oechssler (2002). "Stability of the Cournot Process. Experimental Evidence.“ International Journal of Game Theory 31: 123-136.

Huck, Steffen, Hans-Theo Normann and Jörg Oechssler (2004). "Two are Few and Four are Many. Number Effects in Experimental Oligopolies.“ Journal of Economic Behavior \& Organization 53: 435-446.

Huck, StefFen and Brian WALlace (2002). "Reciprocal Strategies and Aspiration Levels in a Cournot-Stackelberg Experiment.“ Economics Bulletin 3/3: 1-7.

IsAaC, R. MARK and Charles R. Plott (1981a). "The Opportunity for Conspiracy in Restraint of Trade. An Experimental Study.“ Journal of Economic Behavior \& Organization 2: 1-30.

IsAaC, R. MARK and Charles R. Plott (1981b). "Price Controls and the Behavior of Auction Markets. An Experimental Examination.“ American Economic Review 71: 448-459.

IsAaC, R. MARK, VALÉRIE RAMEy and Arlington W. Williams (1984). “The Effects of Market Organization on Conspiracy in Restraints of Trade.“ Journal of Economic Behavior \& Organization 5: 191-222.

Johnson, Michael D. and Charles R. Plott (1989). "The Effect of Two Trading Institutions on Price Expectations and the Stability of Supply-Response Lag Markets.“ Journal of Economic Psychology 10: 189-216.

Jullien, CÉline and Bernard Ruffieux (2001). "Innovation, avantages concurrentiels et concurrence. Une Analyse expérimentelle des incitations à innover et de l'efficacité des marchés en présence de chocs endogènes.“ Revue d'Économie Politique 111: 121-149.

Keser, Claudia (1993). "Some Results of Experimental Duopoly Markets with Demand Inertia.“ Journal of Industrial Economics 41: 133-151.

Keser, Claudia (2000). “Cooperation in Symmetric Duopolies with Demand Inertia.“ International Journal of Industrial Organization 18: 23-38.

KÜBler, Dorothea and Wieland Müller (2002). "Simultaneous and Sequential Price Competition in Heterogeneous Duopoly Markets. Experimental Evidence.“ International Journal of Industrial Organization 20: 1437-1460.

Martini, Gianmaria (2003). "Complexity and Individual Rationality in a Dynamic Duopoly. An Experimental Study.“ Research in Economics 57: 345-370.

Mason, Charles F. and Owen R. Phillips (1997). "Information and Cost Asymmetry in Experimental Duopoly Markets.“ Review of Economics and Statistics 79: 290-299. 
Mason, Charles F., Owen R. Phillips and Clifford Nowell (1992). "Duopoly Behavior in Asymmetric Markets. An Experimental Evaluation.“ 74: $662-670$.

Mestelman, Stuart, Deborah Welland and Douglas Welland (1987). “Advance Production in Posted Offer Markets.“ Journal of Economic Behavior \& Organization 8: 249-264.

Mestelman, Stuart and Douglas Welland (1987). "Advance Production in Oral Double Auction Markets.“ Economics Letters 23: 43-48.

Mestelman, Stuart and Douglas Welland (1988). “Advance Production in Experimental Markets.“ Review of Economic Studies 55: 641-654.

Mestelman, Stuart and Douglas Welland (1991). "The Effects of Rent Asymmetries in Markets Characterized by Advance Production. A Comparison of Trading Institutions.“ Journal of Economic Behavior \& Organization 15: 387-405.

Miller, Ross M., Charles R. Plott and Vernon L. Smith (1977). "Intertemporal Competitive Equilibrium. An Empirical Study of Speculation.“ Quarterly Journal of Economics 91: 599-624.

Morgan, John, Henrik Orzen and Martin Sefton (2006). “An Experimental Study of Price Dispersion.“ Games and Economic Behavior 54: 134-158.

Müller, Wieland (2006). “Allowing for Two Production Periods in the Cournot Duopoly. Experimental Evidence.“ Journal of Economic Behavior \& Organization 60: 100-111.

Muren, Astri (2000). “Quantity Precommitment in an Experimental Oligopoly Market.“ Journal of Economic Behavior \& Organization 41: 147-157.

Muren, Astri and Roger Pyddoke (1999). Does Collusion Without Communication Exist? http://ideas.repec.org/p/hhs/sunrpe/1999_0011.html.

MurPhy, JAMES L. (1966). "Effects of the Threat of Losses on Duopoly Bargaining.“ Quarterly Journal of Economics 80: 296-313.

OECHSSLER, JÖRG and FRANK SCHUHMACHER (2004). "The Limited Liability Effect in Experimental Duopoly Markets.“ International Journal of Industrial Organization 22: 163-184.

Offerman, Theo, Jan Potters and Joep Sonnemans (2002). "Imitation and Belief Learning in an Oligopoly Experiment.“ Review of Economic Studies 69: 973-997.

Orzen, HenRIK (2005). Concentration and Competition. An Experiment http://www.nottingham.ac.uk/economics/cedex/papers/2005-06.pdf. 
PantZ, Katinka and ANTHONy Ziegelmeyer (2004). Collaborative Networks in Experimental Triopolies ftp://papers.econ.mpg.de/esi/discussionpapers/2005-38.pdf.

Phillips, OWen R. and Charles F. MAson (1992). "Mutual Forbearance in Experimental Conglomerate Markets.“ Rand Journal of Economics 23: 395-414.

Plott, Charles R. and Vernon L. Smith (1978). “An Experimental Examination of Two Exchange Institutions.“ Review of Economic Studies 45: 133-153.

Plott, Charles R. and Jonathan T. Uhl (1981). "Competitive Equilibrium with Middlemen. An Empirical Study.“ Southern Economic Journal 47: 1063-1071.

Rassenti, Stephen, Stanley S. Reynolds, Vernon L. Smith and Ferenc Szidarovszky (2000). "Adaptation Convergence of Behaviour in Repeated Experimental Cournot Games.“ Journal of Economic Behavior \& Organization 41: 117-146.

Ruffle, Bradley J. (2000). “Some Factors Affecting Demand Withholding in Posted-Offer Markets.“ Economic Theory 16: 529-544.

Sauermann, Heinz and Reinhard SELten (1959). "Ein Oligopolexperiment.“ Zeitschrift für die gesamte Staatswissenschaft 115: 427-471.

Selten, Reinhard (1967a). Ein Oligopolexperiment mit Preisvariation und Investition. Beiträge zur experimentellen Wirtschaftsforschung. Ernst Sauermann. Tübingen, Mohr: 103-135.

SELten, ReInHARD (1967b). Investitionsverhalten im Oligopolexperiment. Beiträge zur Experimentellen Wirtschaftsforschung I. Ernst Sauermann. Tübingen, Mohr: 60-102.

SELten, ReINHARD (1970). Ein Marktexperiment. Beiträger zur experimentellen Wirtschaftsforschung II. Ernst Sauermann. Tübingen, Mohr: 33-98.

Selten, Reinhard and Claus C. Berg (1970). Drei experimentelle Oligopolspielserien mit kontinuierlichem Zeitablauf. Beiträge zur Experimentellen Wirtschaftsforschung II. Ernst Sauermann. Tübingen, Mohr: 162-221.

Sherman, Roger (1971). "An Experiment on the Persistence of Price Collusion." Southern Economic Journal 37: 489-495.

SHERman, Roger (1972). Oligopoly. An Empirical Approach. Lexington, Mass., Lexington Books.

Shubik, Martin, Gerrit Wolf and Herbert B. Eisenberg (1972). "Some Experiences with an Experimental Oligopoly Business Game.“ General Systems 17: 61-74.

Smith, Vernon L. and Arlington W. Williams (1981). “On Nonbinding Price Controls in a Competitive Market.“ American Economic Review 71: 467-474. 
Smith, Vernon L. and Arlington W. Williams (1982). "The Effects of Rent Asymmetries in Experimental Aucion Markets.“ Journal of Economic Behavior \& Organization 3: 99-116.

Smith, Vernon L., Arlington W. Williams, W. Kenneth Bratton and Michael G. VanNONI (1982). "Competitive Market Institutions. Double Auction vs. Sealed Bid-Offer.“ American Economic Review 72: 58-77.

STOECKER, RolF (1980). Experimentelle Untersuchung des Entscheidungsverhaltens im Bertrand-Oligopol. Bielefeld, Pfeffer.

Suetens, Sigrid (2003). Does R\& Cooperation Facilitate Price Collusion? An Experiment http://greywww.kub.nl:2080/greyfiles/center/2003/doc/99.pdf.

Suetens, Sigrid (2005). “Cooperative and Noncooperative R\&D in Experimental Duopoly Markets.“ International Journal of Industrial Organization 23: 63-82.

Wellford, Charissa PePin (1990). Takeovers and Horizontal Mergers. Policy and Performance. Ann Arbor, UMI.

Williams, Arlington W. (1979). "Intertemporal Competitive Equilibrium. On Further Experimental Results.“ Research in Experimental Economics 1: 255-278.

Williams, ARlington W. (1987). “The Formation of Price Forecasts in Experimental Markets.“ Journal of Money, Credit and Banking 19: 1-18.

Williams, Arlington W. and Vernon L. Smith (1984). “Cyclical Double-Auction Markets with and without Speculators.“ Journal of Business 57: 1-33.

Wolf, Gerrit and Martin SHUBiK (1975). “Teams Compared to Individuals in Duopoly Games with an Artifical Player.“ Southern Economic Journal 41: 635-648. 